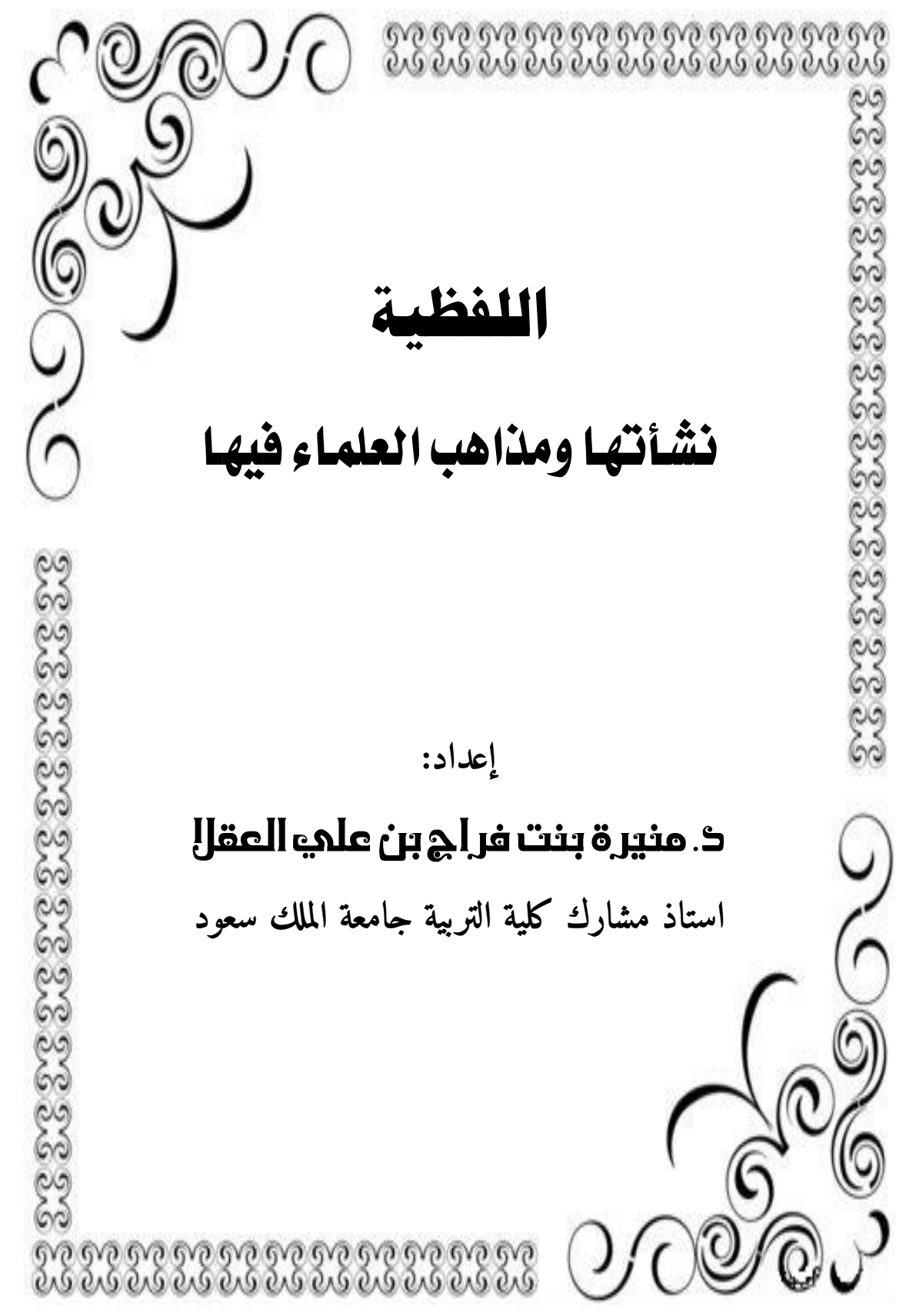




\section{اللفظية نشأتها ومذاهب العلماء فيها}

منيرة بنت فراج العقلا

قسم الثقافة الإسلامية، كلية التربية، جامعة الملك سعود، الرياض، السعودية. البريد الإلكتروني: malogla@ksu.edu.sa

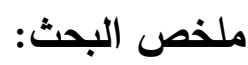

في هذا البحث بيانٌ لمسألة اللفظية، ونشأتها، ومذاهب العلماء فيها، وبيان

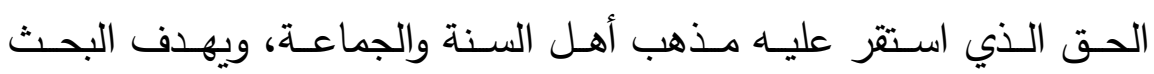
إلى:التعريف بالإمامين أحمد والبخاري، وموقف الأمام أحمد في فتنـة خلق القرآن والبخاري في مسألة اللفظ.روالتفصيل في محنـة خلق القرآن وما ترتب عليها من فتن أخرى ومنها مسألة اللفظ. وبيان المقصود بمسألة اللفظ. وذكر أقوال العلماء في مسألة اللفظ وبين الحق في ذلك.وقد اعتمد البحث على في في المنهج الاستقرائي الاستنباطي. ومن أهم نتائج البحث: - ظهرت فتــة القول بخلق القرآن في عهد المـأمون، وامتُحن فيها العلمـاء ومنهم: الإمام أحمد، الذي نصر الله به الدين. - المقصود باللفظ في البحث: هو قول القائل: "إن اللفظ بالقرآن مخلوق". - أول من قال: "لفظي بالقرآن مخلوق" هو الكرابيسي. - تعددت مذاهب العلماء في هذه المسألة إلى ثلاثة أقوال: الإثبات والنفي والمنع من القولين، وإلى منع القولين ذهب أئعة السلف، واستقر مذهب أهل السنة أن اللفظ لفظ البارئ، والصوت صوت وإئ القارئ. 


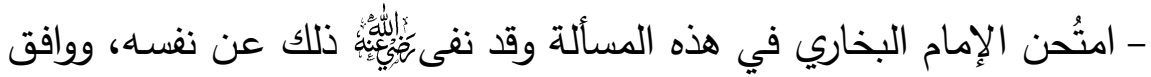

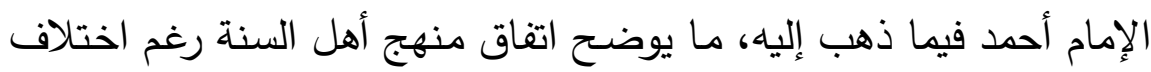

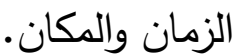
الكلمـات المفتاحية: خلق القرآن- اللفظية- لفظي بالقرآن مخلوق - الإمـام

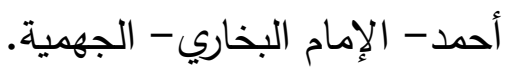


Verbal Its origin and doctrines of scholars in it Munira bint Faraj Al-Aqla

Department of Islamic Culture, College of Education, King Saud University, Riyadh, Saudi Arabia.

Email: malogla@ksu.edu.sa

\section{Abstract:}

In this research there is an explanation of the issue of verbalism, its origin, the doctrines of scholars therein, and an explanation of the truth on which the doctrine of Ahl al-Sunnah wal Jama'ah settled.

Introducing the Imams Ahmad and Al-Bukhari, and the position of Imam Ahmad regarding the temptation of the creation of the Qur'an and al-Bukhari in the issue of pronunciation.

-Detail about the ordeal of creating the Qur'an and the other trials that resulted from it, including the issue of pronunciation.

-Explaining what is meant by the issue of pronunciation.

-He mentioned the sayings of scholars on the issue of pronunciation and showed the truth in that.

The research relied on the deductive inductive approach.

Among the most important results of the search:

-The temptation to say about the creation of the Qur'an appeared in the era of al-Ma'mun, and scholars were tested in it, including: Imam Ahmad, by whom God supported the religion.

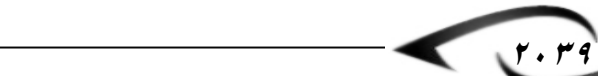


-What is meant by the word in the research: It is the saying of the one who said: "The pronunciation of the Qur'an is created."

-The first person to say: "My phrasing of the Qur'an is a creature" was al-Karabisi.

-The scholars' schools of thought on this issue varied into three sayings: proof, negation, and prohibition of the two sayings, and to the prohibition of the two sayings, the imams of the predecessor went, and the Sunnis doctrine established that the word pronounced al-Bari, and the voice was the voice of the reciter.

Imam Al-Bukhari was tested on this issue and he denied this on his own behalf, and Imam Ahmad agreed with what he went to, which explains the agreement of the Sunnis' approach despite the difference in time and place.

keywords : Creation of the Qur'an-verbal- verbal Qur'an a creature- Imam Ahmad- Imam Bukhari- Jahmiyya. 


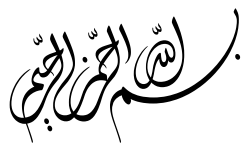

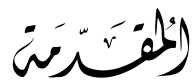

"إن الحمـــ الله نحمـده و نسـتعينه ونسـتغفره ونعـوذ بـالله مـن شـرور أنغسـنا وسيئات أعمالنا، من يهد الله فهو المهتد، ومن يضلل فلا هادي لله وأشهد أن أن

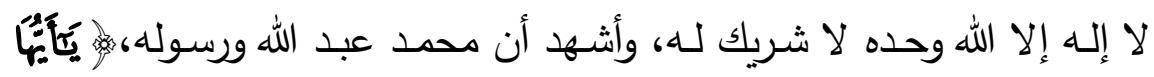

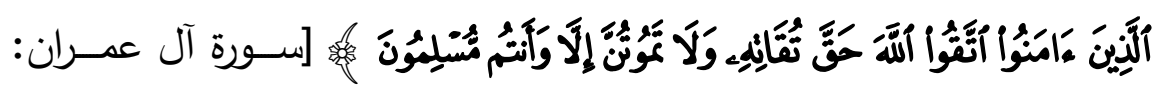

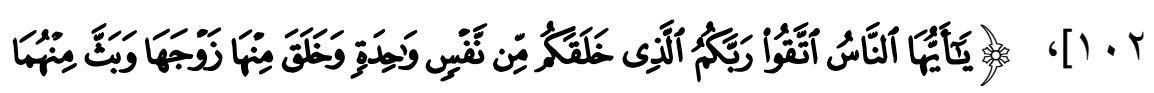

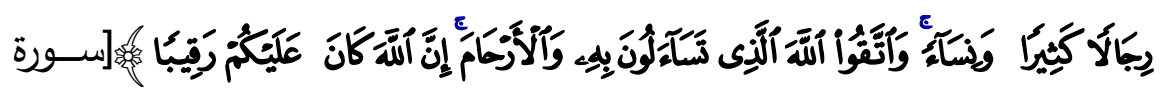

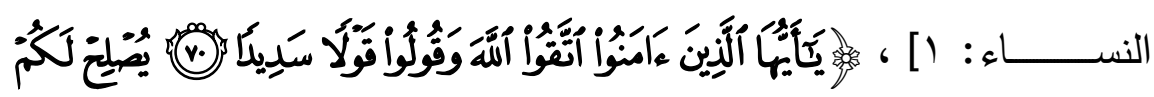

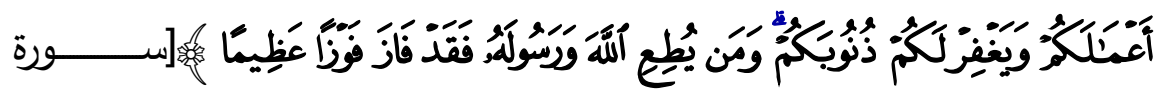

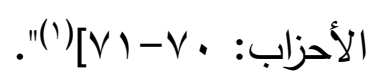

أما بعد، فإن أهم مسائل العلم ومباحث الدين هو الإيمان بالله سبحانه وتعالى وأسمائه الحسنى وصفاته العلى، ذلك أن شرف العلم بشرف المعلوم لوثوق

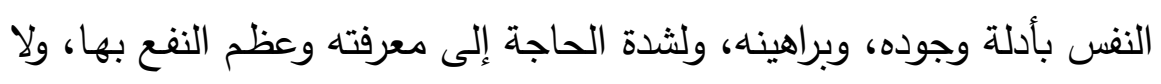

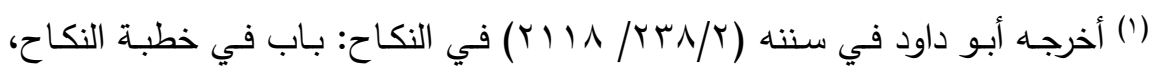

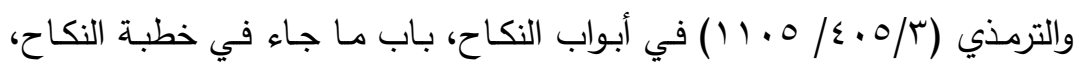

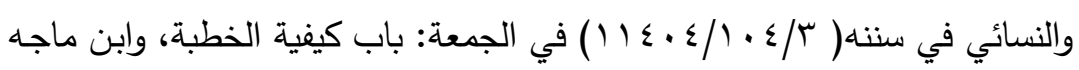

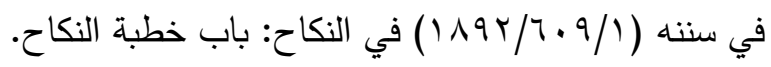

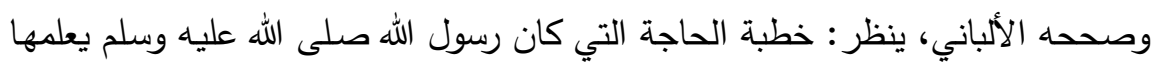
أصحابه للألباني "الرسالة كاملة". 
ريب أن أجل معلوم وأعظمه وأكبره هو الله الذي لا إله إلا هو رب العالمين، فكل خير في الدنيا والآخرة متوقف على الإيمان الصحيح به تعالى وبأسمائه وصفاته جل ، وبالإيمـان بـه يحيى العبد حياة طيبة في الدارين، قال ابن القيم: "أفضل ما اكتسبته النفوس وحصلته القلوب ونال به العبد الرفعة في الدنيا والآخرة هو العلم والإيمان ولهذا قرن بينهما سبحانه في قولـه تعالى

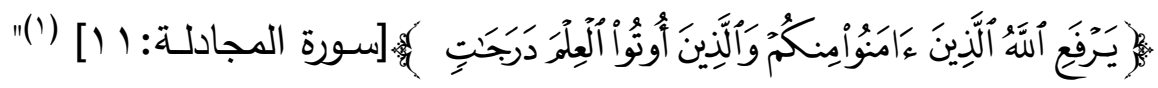

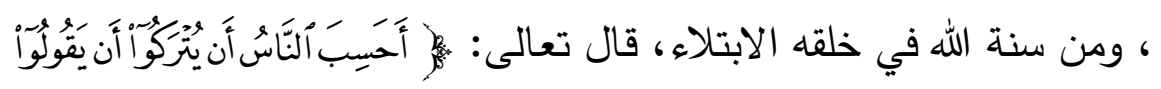

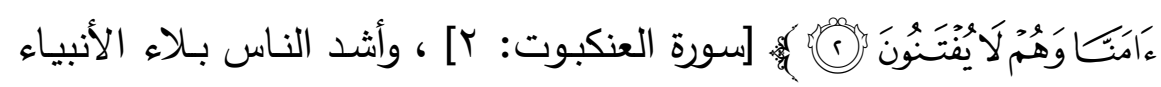

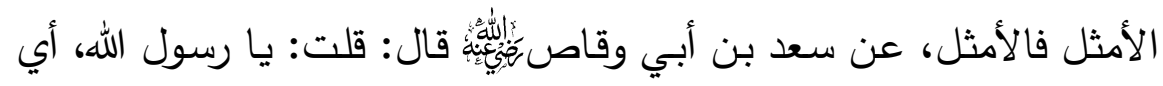
الناس أشد بلاء؟ قال: "الأنبياء، ثم الأمثل فالأمثل، يبتلى العبد على حسب الإب دينه، فإن كان في دينه صلبا اشتد بلاؤه، وإن كان في دينه رقة ابتلي على حسب دينه، فما يبرح البلاء بالعبد حتى يتركه يمشي على الأرض، وما عليه

من خطيئة" (r).

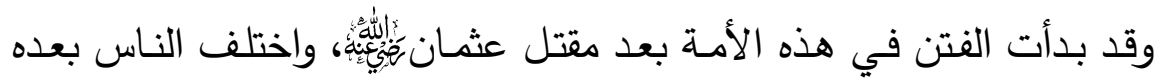
فظهرت الخوارج ثم الروافض ثم القدرية ثم المعتزلة والجهمية، وترجمت كتب اليونان في عهد المأمون فرفعت الجهمية والمعتزلة رؤوسها وجعلوه يحمل الأمة على خلق القرآن، وما تبعها من فتن ومحن.

(') ينظر : مختصر الصواعق المرسلة على الجهمية والمعطلة (ص: V V ).

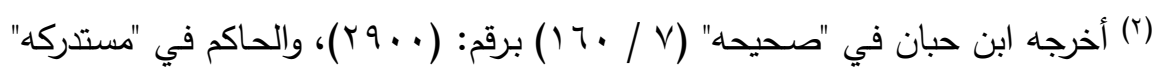

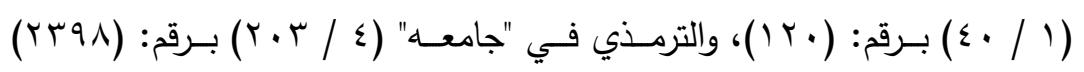

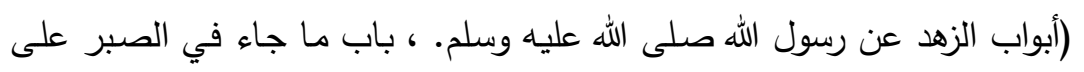
البلاء ). وقال: هذا حديث حسن صحيح. 
أدت فتنة القول بخلق القرآن التي ثبت فيها الإمام أحمد على قول الحق إلى

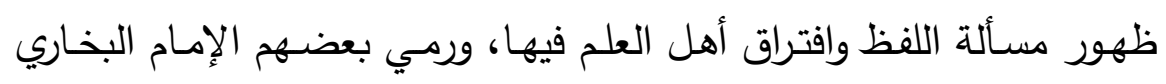

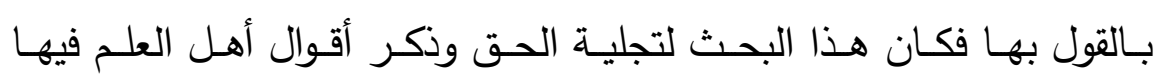
وترجيحهم، وبيان ثبات الإمام البخاري على الحق.

حدود البحث:

سيقتصر البحث على مسألة اللفظ وسبب ظهورها وهي فتتة القول بخلق القرآن، وأقوال العلماء في مسألة اللفظ وذكر محنة الإمام البخاري، وتجلية موقفه فيها. أهمية الموضوع وسبب اختياره:

1- تعرض العلماء لمحن عديدة في دينهم، وثباتهم كان سببًا لحفظ

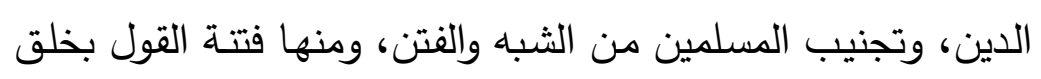

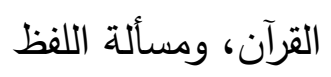

r- الحاجة إلى التعرف على مواقف الأئعة من الفتن والنوازل واتخاذهم قدوة في الثبات. ץ- بيان وحدة منهج العلماء في التعامل مع الفتن. أهداف البحث:

1- التعريف بالإمـامين أحمد والبخاري، وموقف الأمام احمد في فتنـة خلق القرآن والبخاري في مسألة اللفظ. 
ץ- التفصيل في محنة خلق القرآن وما ترتب عليها من فتن أخرى ومنها

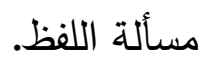

ץ- ذكر الأسباب التي أدت لهذه المحن، والآثار المترتبة عليها. ع- بيان المقصود بمسألة اللفظ.

0- ذكر أقوال العلماء في مسألة اللفظ وبين الحق في ذلك.

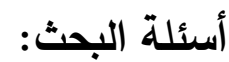

ماهي محنة خلق القرآن وما ترتب عليها من فتن أخرى؟ ما الأقوال في مسألة اللفظ، ومتى نشأت وما السبب في ظهورها؟ ما هو موقف الإمام أحمد في فتتة القول بخلق القرآن؟ ما هو موقف البخاري من مسألة اللفظ؟

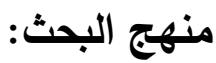
المنهج الاستقرائي الاستتباطي.

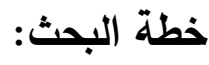
تتكون الخطة من مقدمة وتمهيد وثلاثة مطالب. المقدمة، وفيها: أهمية الموضوع وأسباب اختياره، ومشكلة البحث، وحدوده،

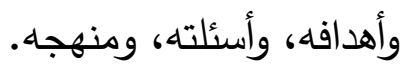

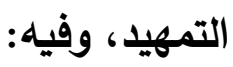
التعريف بالإمام أحمد. فتنتة القول بخلق القرآن. 
المطلب الأول: التعريف باللفظية، وفيه مسألتان:

المسألة الأولى: تعريف اللفظية.

المسألة الثانية: نشأة القول باللفظية.

المطلب الثاني: مذاهب العلماء في اللفظية.

المطلب الثالث: محنة الإمام البخاري، وفيه مسألتان:

المسألة الأولى: التعريف بالإمام البخاري.

المسألة الثانية: محنة الإمام البخاري في مسألة اللفظ.

الخاتمة.

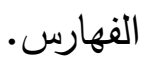




\section{التمهيا}

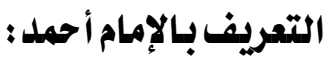

نسبه ونثـأتها: هو أبو عبدالله أحمد بن محمد بن حنبل بن هلال بن أسد

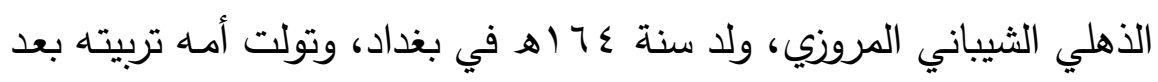
وفاة أبيه وهو صغير (1). طلبه للعلم: طلب الحديث وهو في الخامسة عشرة من عمره في البصرة، ثم ذهب إلى مكة وإلى اليمن وسمع الحديث من شيوخ كثر (ז) زاد عدهم عن مائتين وثمانين، وروى عنه خلق كثير (ז)، وكان إمام المحدثين، صنف كتابه المسند وجمع فيه من الحديث ما لم يتفق لغيره. صـفاته: اتصفف بـالورع والزهد والبر لأمسه، والـكاء وقوة الحفظ والخشـوع والتعفف والتواضع والقوة في الحق(£). وفاتـهـ: توفي سـنة اءكابه في يـوم الجمعـة الثاني عشر مـن ربيع الأول،

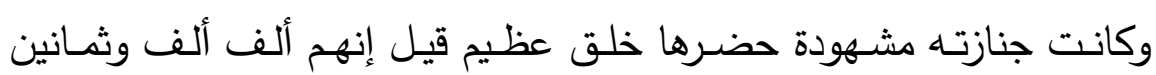
ألثفًا (०). (2)

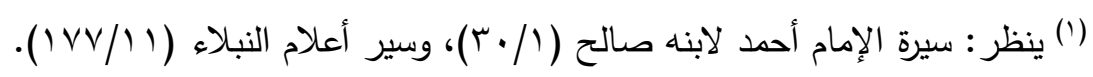
(r) منهم الفضيل بن عياض وعبدالرزاق وسفيان بن عيينة ووكيع والثافعي وغيرهم.

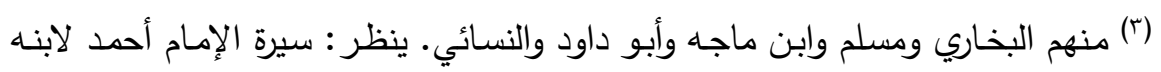

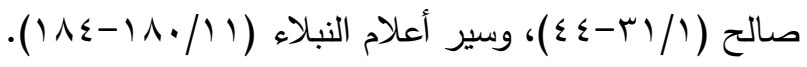

$$
\begin{aligned}
& \text { (؛) ينظر : المرجعان السابقان. } \\
& \text { (0) - (0) ينظر : المراجع السابقة. }
\end{aligned}
$$




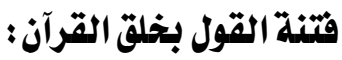

لما تولى المأمون ('الخلافة، ظهرت الدعوة إلى القول بخلق القرآن، وتولى كبرهـا أحمـد بـن أبـي دؤاد (r)، الذي كـان رأس الفتــة؛ وكـان المـأمون مـائلا للمعتزلة، فلم يُحمل الناس على القول بخلق القرآن إلا بعد تولي المـأمون،

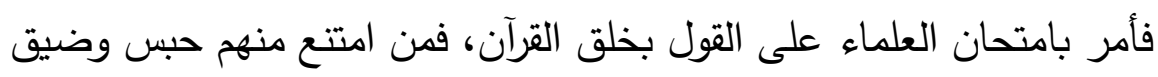

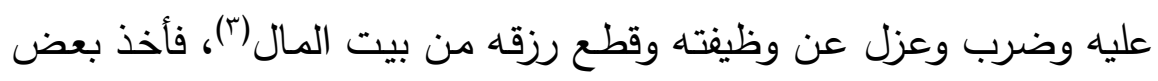

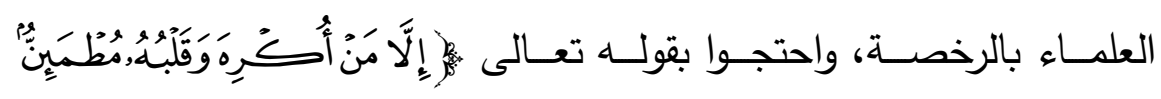

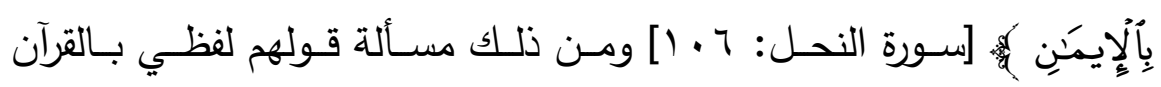
مخلوق، ولم يثبت سوى قلة من العلماء، وعلى رأسهم الإمام أحمد فكان يرد

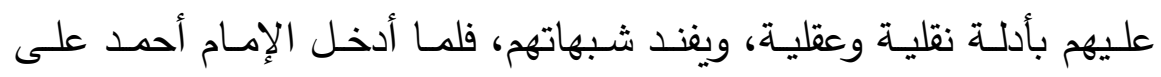
إسحاق بن إبراهيم (أللمحنة فقرئ عليه الكتاب الذي أرسل إلى طرموس فكان

(') عبدالله بن هارون أمير المؤمنين، أبو العباس المأمون بن الرشيد بن المهدي، ولد سنة

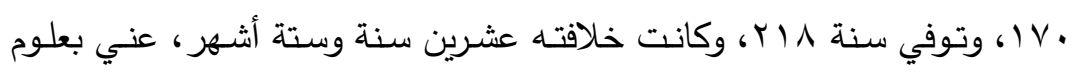
الأوائل ومهر في الفلسفة، فجره ذلك إلى القول بخلق القرآن، ينظر : وفيات الأعيان

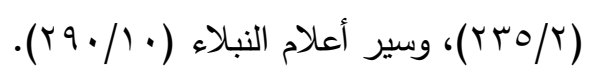

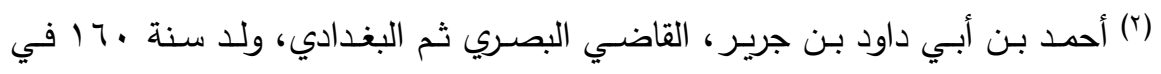

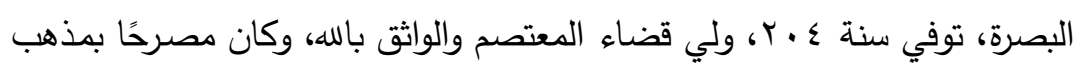
الجهمية، داعية إلى القول بخلق القرآن، ينظر : تاريخ الإسلام (VON/0).

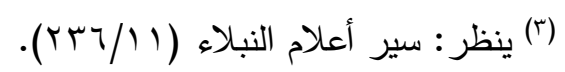

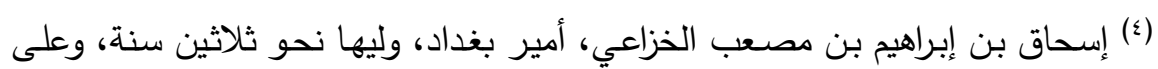

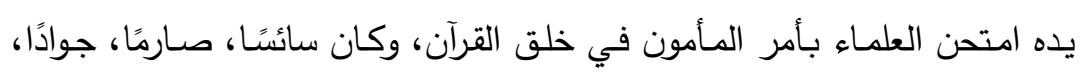

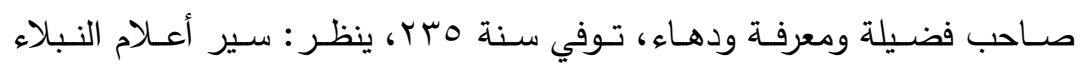
.$(r \circ 1 / 9)$ 
فيما قرئ: (ليس كمثله شيء وهو على كل شيء قدير)، فقال: (وهو السميع

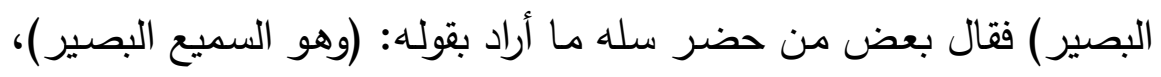

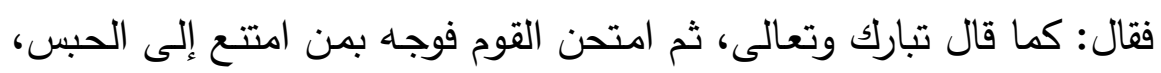

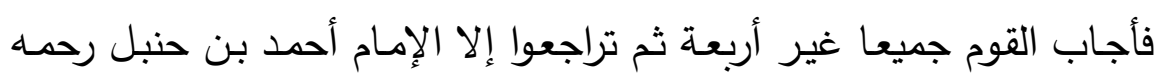

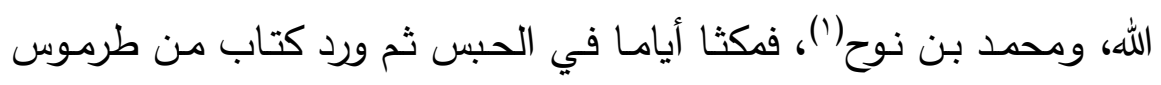

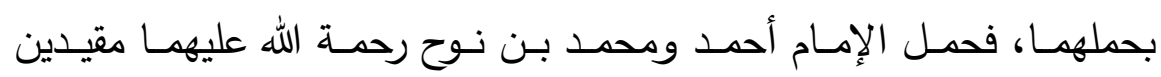

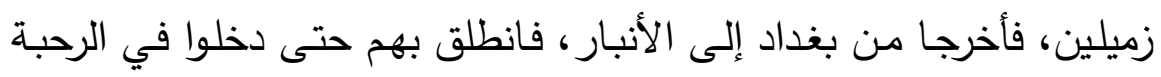

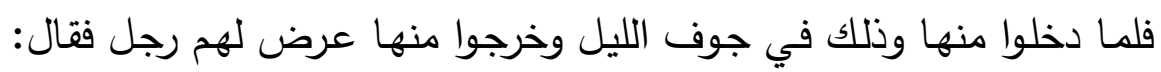

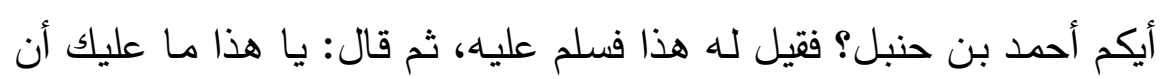

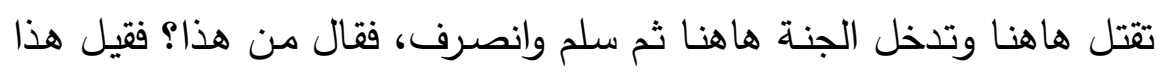

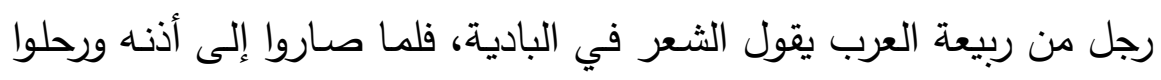

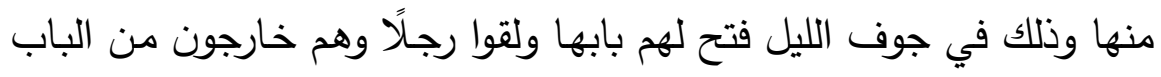

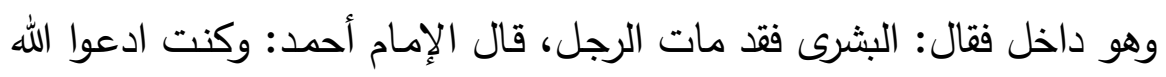

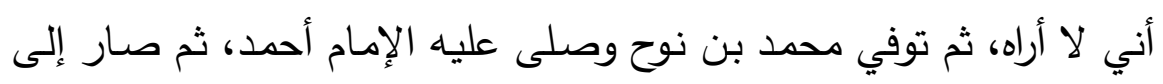

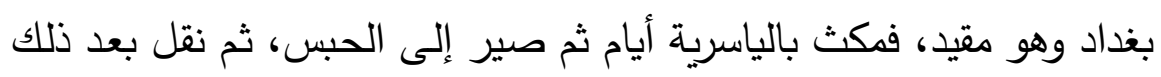

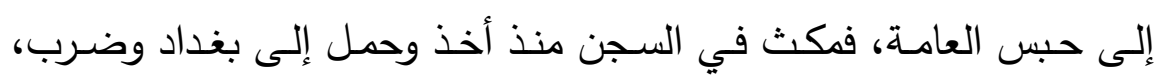
ودخل عليه ثمانية وعشرين شهرا، فكان يصلي بهم وهو مقيد (؟).

(1) محمد بن نوح بن ميمون بن عبد الحميد بن أبي الرجال العجلي، كان أجد المشهورين

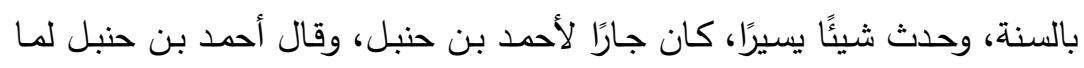

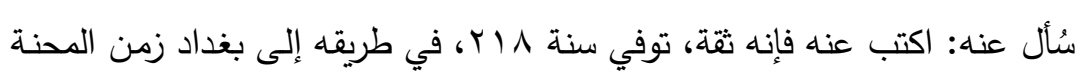

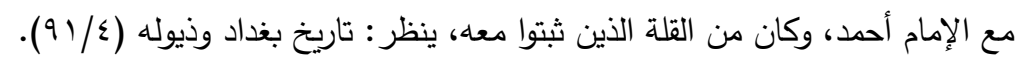

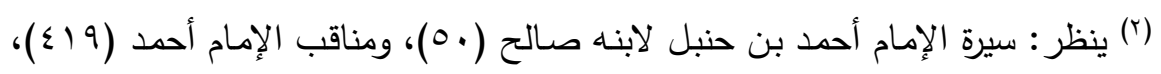
$==$ 
يظهر من هذا عظم الفتنة فلم يثبت إلا أربعة من العلماء، تراجع منهم اثنان، ثم توفي محمد بن نوح، وبقي الإمام أحمد وحده ثابتًا، ولو أجاب لانساقت

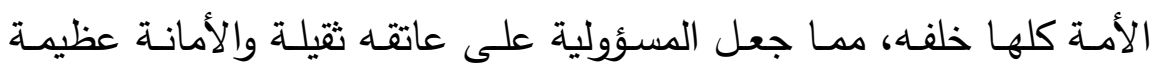

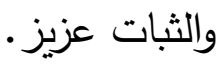

الفتنة في عهد المعتصم:

استمر المعتصم على منهج المـأمون في امتحان الإمام أحمد بالقول بخلق

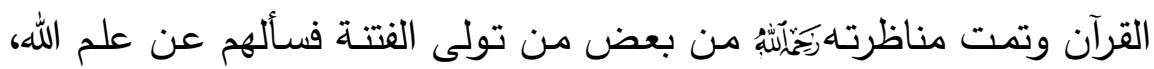
فقال: علم الله مخلوق، فقال الإمـام أحمد: إن هذا كفر؛ لأن أسماء الله في

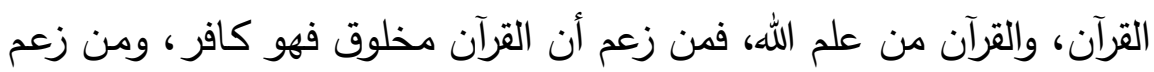
أن أسماء الله مخلوقة فقد كفر (')

فأصل فتنة القول بخلق القرآن لها علاقة بالقرآن من جهة كونهه مخلوقًا أولًا، ومن جهة أسماء الله وصفاته هل هي مخلوقة أم لا؟

ثم عظمت الفتنة وتوعد المعتصم الإمام أحمد بالتعذيب وأمر بإحضـاره إليه،

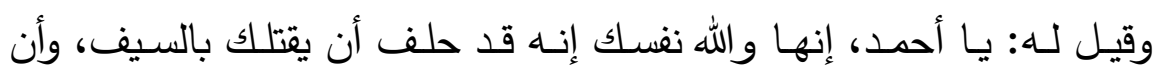
يضربك ضربًا بعد ضرب، وأن يلقيك في موضع لا ترى فيه الشمس أليس قال الله تعالى:

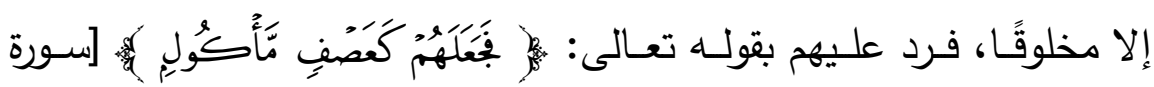
الفيل:0] أفخلقهم.

$$
\begin{aligned}
& \text { ومنحة الإمام أحمد (ع)م). }
\end{aligned}
$$

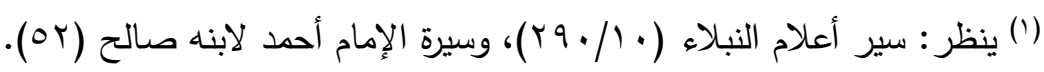


ثم جرت المناظرة بين الإمام أحمد وابن أبي دؤاد، فكان الإمام أحمد يطلب دليلًا من الكتاب أو السنة، فيرد عليه بأنه ضال مضل، ومما ناظروه به:

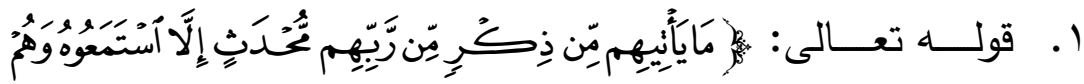

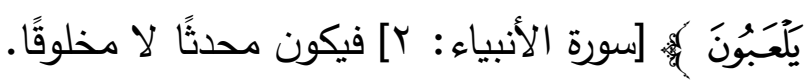

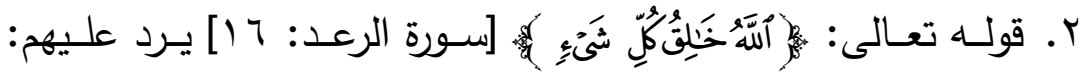

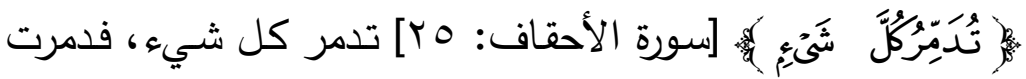

$$
\text { إلا ما أراد الله. }
$$

واستمر الحال على ذلك، يأمر بمحاورته ثم يغضب، فيأمر بجلده، ثم يسأله أن ينقذ نفسه ويجيبه إلى القول بخلق القرآن، فيمتنع الإمام أحمد فيعود الجلد من جديد، فصبر الإمـام على الجراح، وأبى أن يفطر وهو صسائم مـع شدة التعذيب، وثبت ثباتًا عظيمًا، فقد كان يسعه ما وسع غيره من العلماء من التقية والرخصة، لكن رده عن ذلك مكانته في الأمة. يقول المروذي (')أنه قال للإِمام أحمد وآخر معـه: "يا أستاذ قال الله:

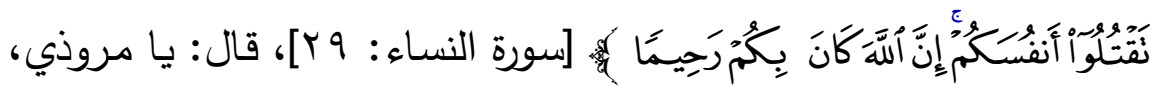
اخرج وانظر ، فخرجت إلى رحبة دار الخلافة، فرأيت خلقًا لا يحصيهم إلا الله، والصـحف في أيـديهم، والأقـلام والمحـابر، فقـال لهـم المـروزي: مـاذا

(') أحمد بن محمد بن الحجاج، أبو بكر، المعروف بالمروذي، كان إمامًا في السنة،

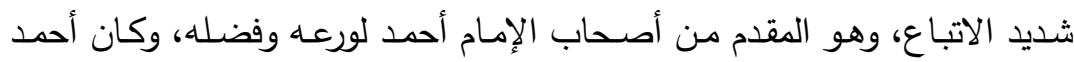

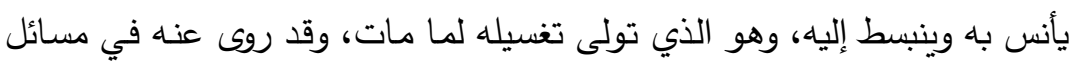

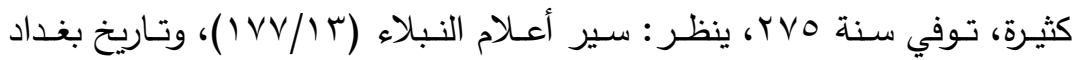

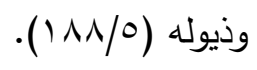


تعملـون؟ قـالوا: ننظـر مـا يقـول أحمـد، فنكتبـه، فـدخل، فـأخبره، فقـال: يـا

مروذي، أضل هؤلاء كلهم"('). قال ابن الجوزي: "هذا رجل هانت عليه نفسه في الله فبذلها، كما هانت على بـلال نفسـه...وإنما تهون أنفسهم عليهم لتحملهم العواقب، فعيون البصـائر ناظرة إل المآل لا إلى الحال، وشدة ابتلاء الإمـام أحمد دليل على قوة دينه،

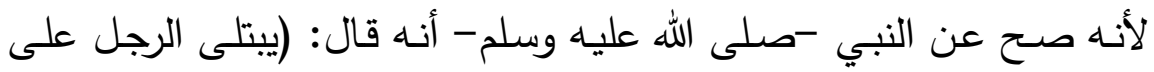
حسب دينه)(؟)، فسبحان من أيده وبصره، وقواه ونصره"(r). انقضاء الفتنة:

لما تولى الواثق (؛)أرسل للإمـام أحمد أن يظل في بيته، ولا يخرج لا للصـلاة

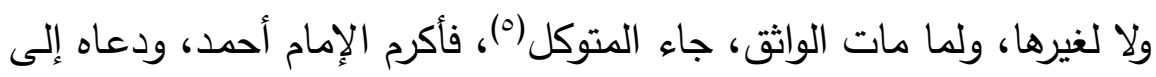

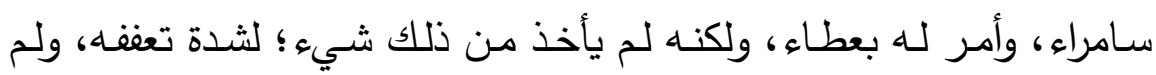
يسكن الدار التي أنزله إياها، بل اكترى دارًا من ماله. هذا مجمل فتنة القول بخلق القرآن، وهي الفتنة التي تفرع عنها القول (لفظي

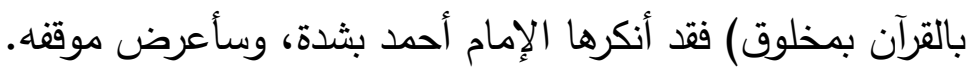

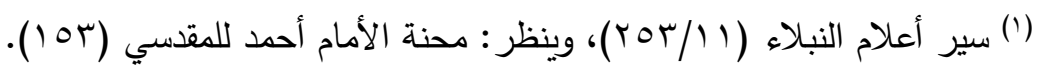

$$
\begin{aligned}
& \text { (r) سبق تخريجه. }
\end{aligned}
$$

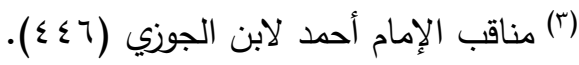

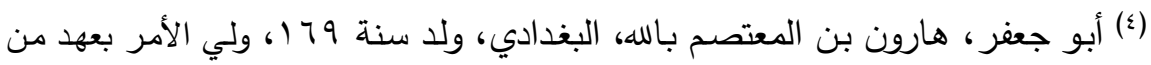

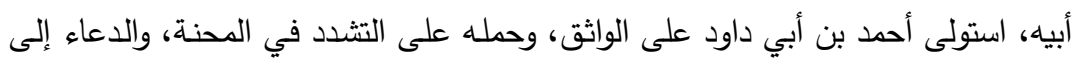

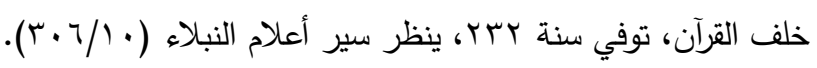

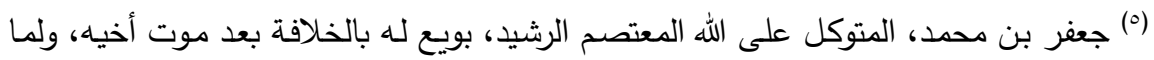

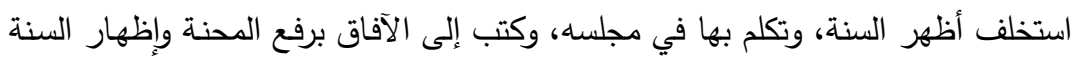

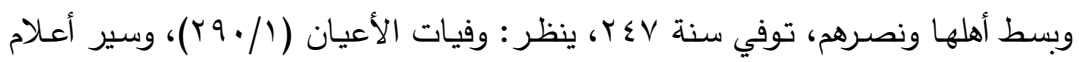

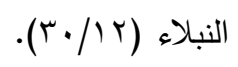




\section{المطلب الأول: التعريف باللفظية}

\section{المسألة الأولى : تعريف اللفظية}

اللفــ لغـةًً: مصـدر الفعـل لَفَظَ يَلْفِظ لَفْظَاً، و(الـلام والفـاء والظـاء) أصـل صحيح يدل على طرح الثيء، والغالب أن يكون من الفم('). ولفظ بقول حسن: تكلم به وتلفظ به(r)، فهو مصدر استعير منه لفظ الثيء من الفم فصـار بمعنى الملفوظ، ومنـه الدنيا لافظـة بمن فيها إلى الآخرة،

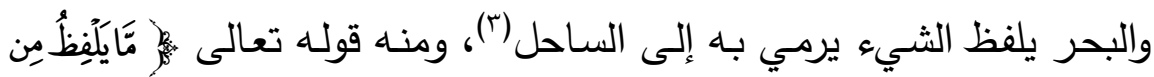

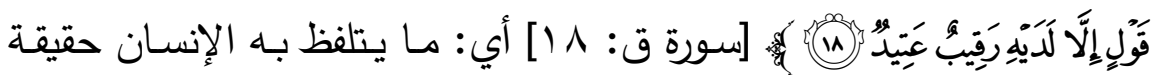
كان أو حكمًا مهملًا كان أو موضوعًا مفردًا أو مركبًا (£.). اللفــ شـرعًا: مـا يـتكلم بـهـ الإنسـان حقيقـةً أو في حكمـهـ مهــلاً كـان أو مستعملاً أو موضوعاً مفرداً أو مركباً (ه). وقيل: اللفظ هو القول الذي يلفظ بـه اللافظ، وقيل: كل لفظ وضـع لمعنى، كما أن اللغات: عبارة عن الألفاظ الموضوعة للمعاني(؟).

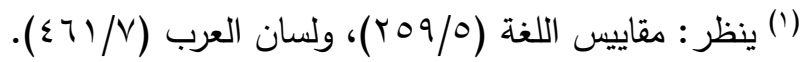

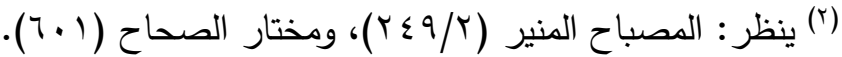

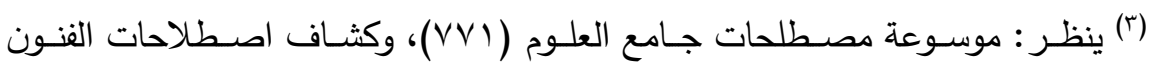

$$
\text { ( ( } 1 \leqslant 1 \cdot / r)
$$

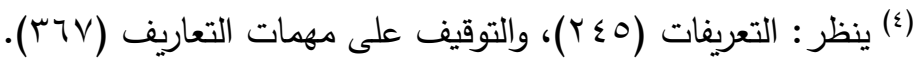

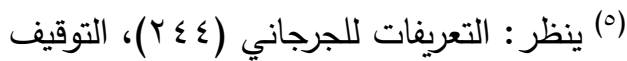

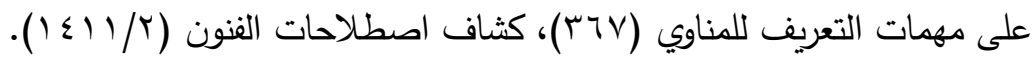
(†) ينظر : المزهر في علوم اللغة (1/1). 
والمراد مطلق التلفظ، فيدخل فيه كلام الله تعالى، وكلام الملائكة، والجن. اللفظ الحقيقي كزيـد، وضـرب، والحكمي كالضـمائر، ونحوهـا، المهمل: هو الذي لـم يوضـع لمعنى، والموضـوع: إمـا مفـرد أو مركب، وهـو الموضـوع لمعنى من المعاني.

فلكل شيء أربع وجودات: وجود عيني وعلمي ولفظي ورسمي، ووجود في الأعيان والأذهان واللسان والبنان.

قال في شرح الطحاويـة: "أن المخاطب لا يفهح المعاني المعبر عنها باللفظ

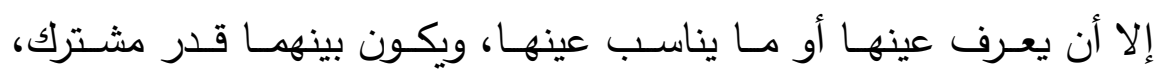
ومشابهة في أصل المعنى، كيف... وآدم أبو البشر أول ما علمه الله تعالى ولى لئل

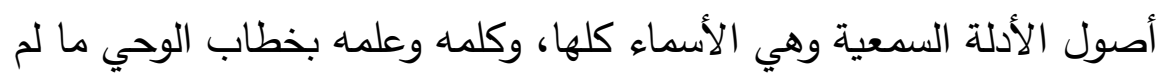

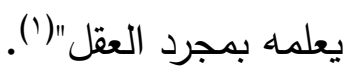

والمقصود باللفظ في هذا البحث هو قول (أن اللفظ بالقرآن مخلوق) وهي مسألة ظهرت بعد فتنة القول بخلق القرآن.

\section{المسألة الثانية : نشأة القول بـاللفظية}

عقب فتــة القول بخلق القـرآن نشـأت مباحث كلاميـة رديئة، منهـا: القول باللفظية، ولم تظهر إلا في زمن الإمام أحد وهو الذي تصدى لها أولاً وبين كفر قائلها، قال ابن جرير : "وأما القول في ألفاظ العباد بالقرآن فلا أثر فيه نعلمـه عن صـحابي مضـى، ولا عن تـابعي قفى، إلا عمن في قولـه الثفا

(1) شرح الطحاوية لابن أبي العز (1/.71). 
والغناء، وفي اتباعه الرشد والهدى، ومن يقوم لدينا مقام الأئمة الأولى أبي

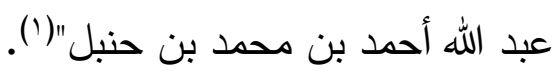

وأول من أظهر هذه المسألة هو حسين بن علي الكرابيسي(؟)، وكان طالبًا

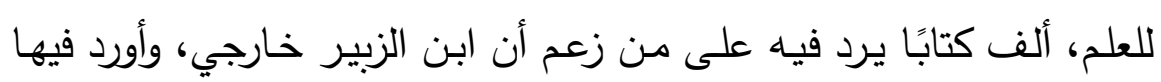

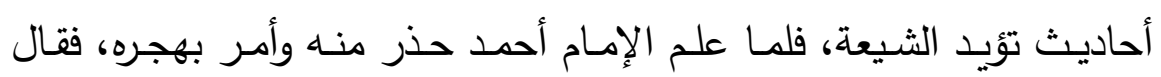

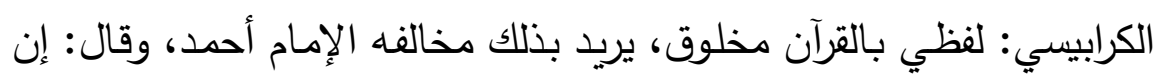

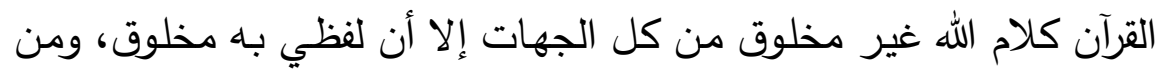

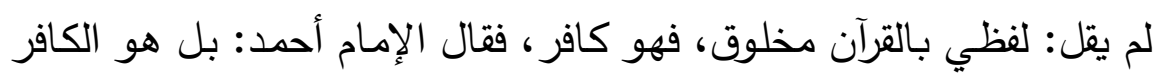

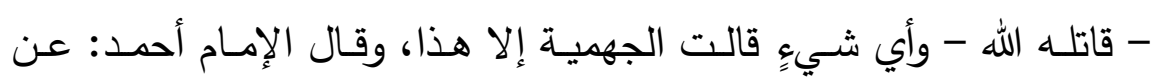
حسين الكرابيسي: "قد خلف هذا بشرا المريسي" ("). وحذر الإمـام أحمد منهه فقال: "إيالك وَإِيَّاك هذا الكرابيسي"(()، وجماعة من السلف(0).

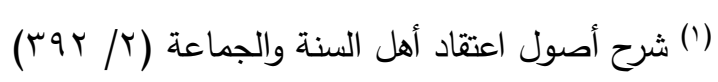

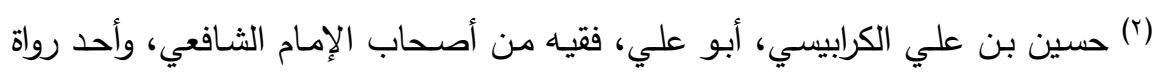

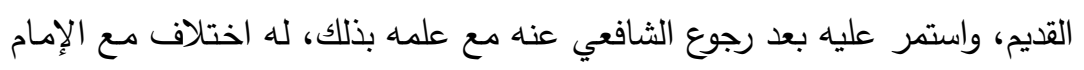

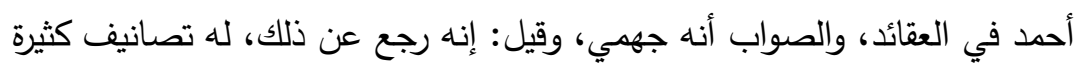

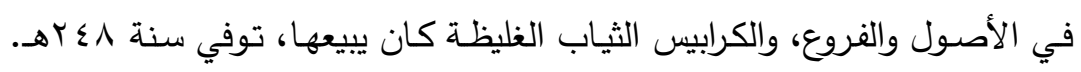

$$
\begin{aligned}
& \text { ينظر : تاريخ بغداد (1)/(7) (7). }
\end{aligned}
$$

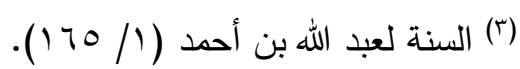

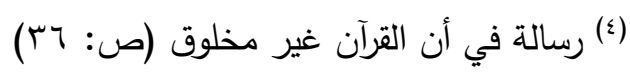

(0) منهم: أبو ثور، والحسن بن محمد الزعغراني، وغيرهم. ينظر : السنة لعبدالله بن أحمد الحدا .$(170 / 1)$ 
ولابد أن يعلم أن هناك فرقًا بين اللفظ والملفوظ:

1- الملفوظ نفسـه هو القرآن، وهو غير مقدور للعبد، ولا فعل لـه

فيه، فهو كلام الله غير مخلوق.

ץ- التلفظ به والأداء له وهو فعل العبد، فإطلاق الخلق على اللفظ، قد يوهم المعنى الأول، وإطلاق نفي الخلق على اللفظ، قد يوهم المعنى الثاني، وهو خطأ. 


\section{المطلب الثاني : مذاهب العلماء في اللفظية}

مسـألة اللفظيـة اضطرب فيهـا أقوام لهـم علم وفضـل وديـن وعقل، وجـرت بسببها مخاصمات ومهاجرات بين أهل الحديث والسنة، حتى قال ابن قتيبة: إن أهل السّنة لم يختلفوا في شيء من أقوالهم إلا في مسألة اللفظ('). وقد تعددت مذاهب العلماء في اللفظية إلى ثلاثة مذاهب: المذهب الأول: من قال: لفظي بالقرآن مخلوق(؟)، وقد نسب هذا القول إلى غير واحد من المعروفين بالسنة والحديث: كالحسين الكرابيسي، ونعيم بن

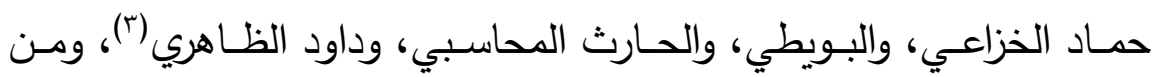

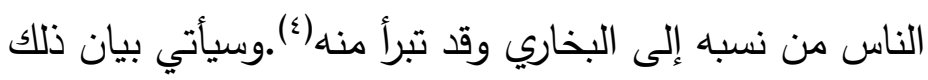
وهؤلاء هم المسمَّون باللفظية، وهي فرقة نشأت قبل الأشـاعرة، وعدهم الإمام أحمد من الجهمية فقال: "افترقت الجهمية على ثلاث فرق: فرقة قالوا: القرآن مخلوق، وفرقة قالوا: كلام الله وتسكت، وفرقة قالوا: لفظنا بالقرآن مخلوق،

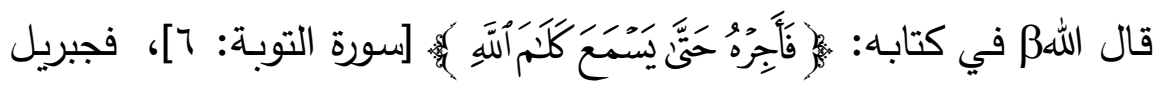

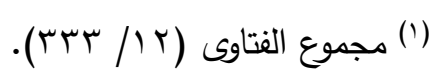

(r) تسترت الجهمية القائلون بخلق القرآن، بقول: ألفاظنا بالقرآن مخلوقة، ومـرادهم: أن

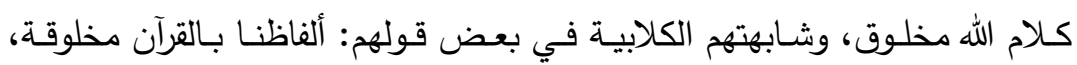

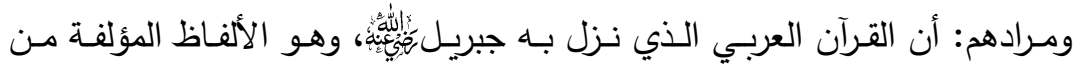

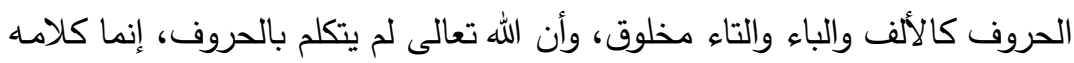

$$
\text { معنى مجرد عن الألفاظ وهذا قديم غير مخلوق. }
$$

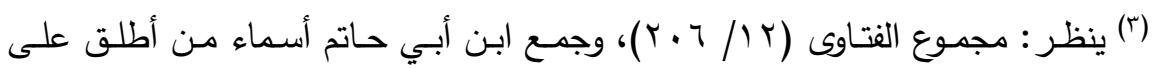

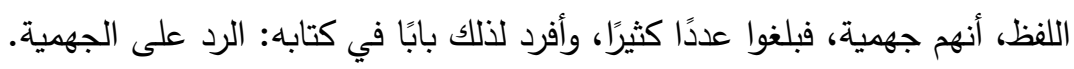

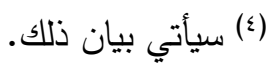




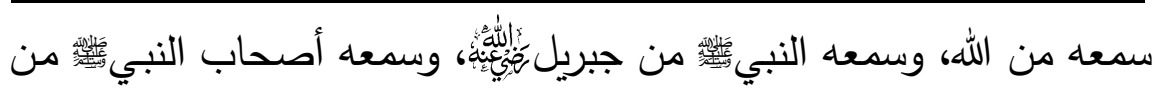

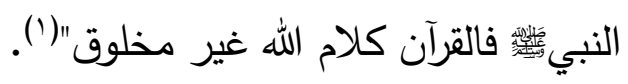

المذهب الثاني: من قال: لفظي بالقرآن غير مخلوق، وإليه ذهب طائفة من

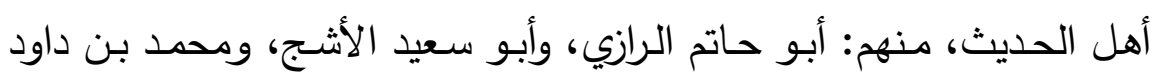
المصيصسي، وأبـو عبد الله بـن منـده، وأبـو نصـر السـزي، وأبـو إسـماعيل

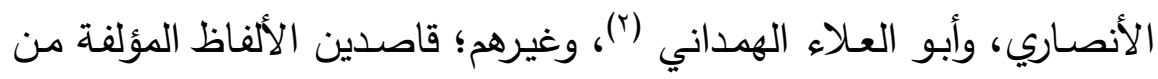

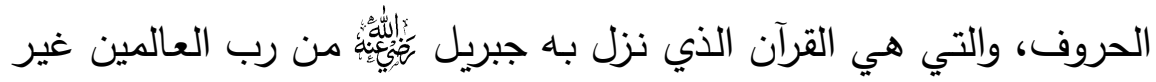

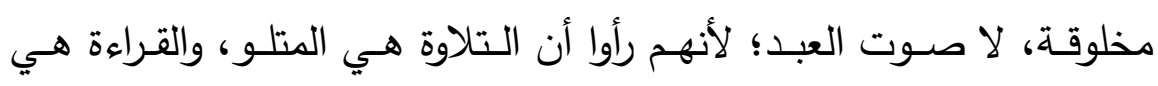
المقروء، فلا يفرقون بين صوت القارئ بالقرآن، ولا المقروء فيجعلونها شيئاً واحداً وكلاهما غير مخلوق، وذلك لما رأوا تضمن قول الجهمية والكلابية: (لفظي بالقرآن مخلوق) معنى بـاطلً، أطلقوا القول بضـد مقالتهم، فقـالوا: ألفاظنا بالقرآن غير مخلوقة، وكان في قولهم إيهام إدخال فعل العبد فيـه، وقد تبعتهم طائفة على مقالتهم وأدخلوا في إطلاقها صـوت العبد بـالقرآن وفعله، وفي أتباع هؤلاء من قد يدخل صوت العبد أو فعله في ذلك، أو يقف

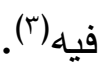

المذهب الثالث: المنع من إطلاق القولين السابقين: اللفظ بالقرآن مخلوق، وغير مخلوق، وأن القرآن كلام الله ووحيه وتتزيله، بألفاظه ومعانيه، ليس هو اليسن

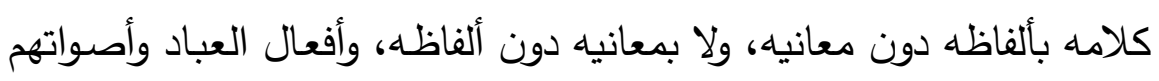

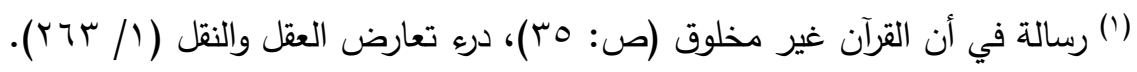

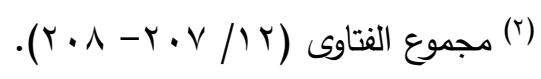

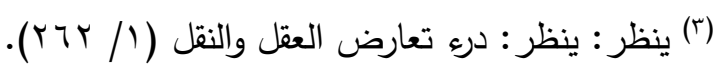


مخلوقة، والعبد يقرأ القرآن، فالصـوت صـوت القارئ، والكلام كـلام الباري، وإليه ذهب أئمسة أهل السنة والاتباع -كالإمـام أحمد والبخاري وأتباعهما (')،

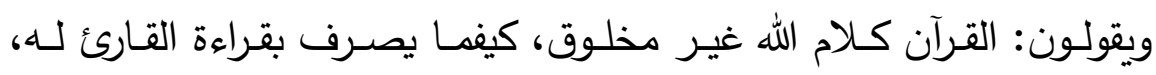
وبلفظه، ومحفوظا في الصدور، متلوًا بالألسن، مكتوبًا في المصـاحف، غير

(1) ينظر : شرح السنة للبربهاري (ص: 90)، شرح أصول اعتقاد أهل السنة والجماعـة

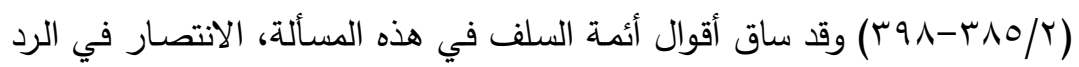

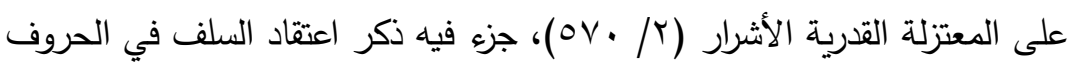

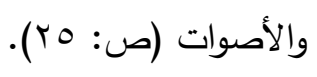

أراد الأشاعرة موافقة أهل السنة في الإنكار على من قال: لفظي بالقرآن مخلوق، ومن

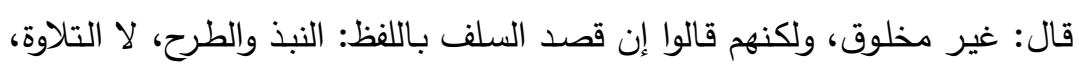
ومنه قولك: (لفظت باللقمة) إذا طرحتها، وهذا المعنى لا تجوز إضافته إلى القرآن. وهذا تفسير الأشعري، وابن الباقلاني، والقاضي أبي يعلى، وإنما قالوا بذلك ليسلم

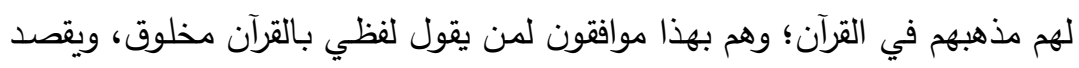

به التلاوة. ولا شك في بطلان قولهم، فإن أحمد وغيره لم ينكروا إطلاق اللفظ لأن المقصود بـهـ

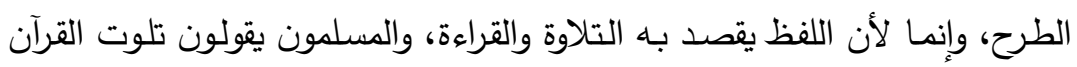

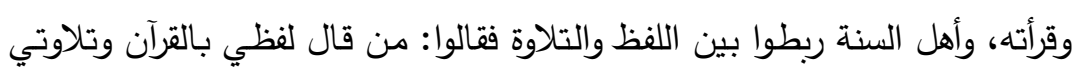

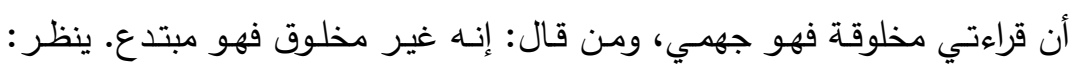

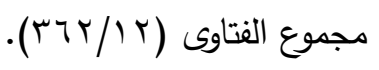

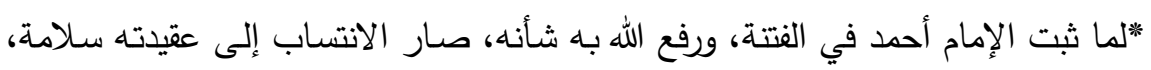
والحيد عنها بدعة، وكل طائفة تنسب اعتقادها إليه.

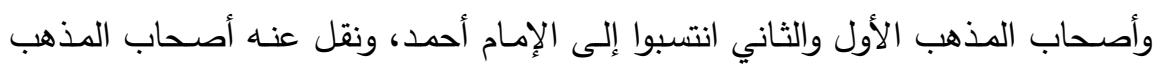
الأول أنه قال: (لفظي بالقرآن مخلوق)، ونقل عنه أصحاب المذهب الثناب الثاني أنه قال:

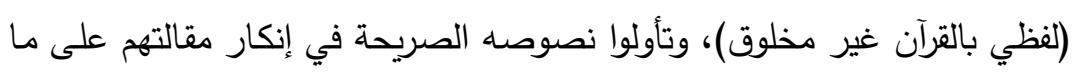
يوافق أهواءهم، والنقل المتواتر عن الإمام أحمد يكذب انتسابه إلى المذهبين. 
مخلوق، ومـن قال بخلق اللفظ بالقرآن يريد بـه القرآن، فهو قد قال بخلق

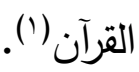

قال ابن جرير الطبري: "أما القول في ألفاظ العباد بالقرآن فلا أثر فيه نعلمه عن صحابي مضى، ولا عن تابعي قفا، إلا عن من في قوله الثفا والغناء، وفي اتباعـ الرشد والهدى ومن يقوم لدينا مقام الأئمسة الأولى: أبي عبد الله أحمد بن محمد بن حنبل-ونقل عنه أنه قال: اللفظية جهمية، وقال: من قال: لفظي بالقرآن مخلوق، فهو جهمي، ومن قال: غير مخلوق، فهو مبتدع...ولا قول عندنا في ذلك يجوز أن نقول غير قوله إذ لم يكن لنا إمام نأتم بـه سواه وفيه الكفاية والمقنع وهو الإمام المتبع"(r). وهذا هو الحق الذي دل عليه الكتاب والسنة، فـإن السلف والأئمسة متفقين

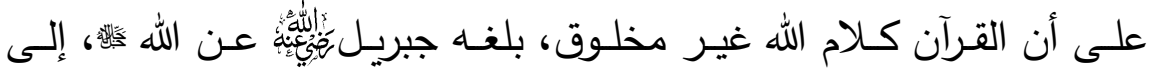

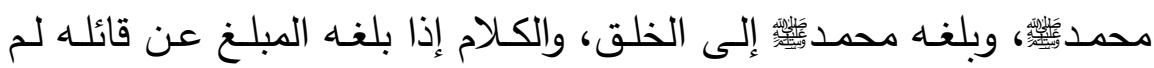

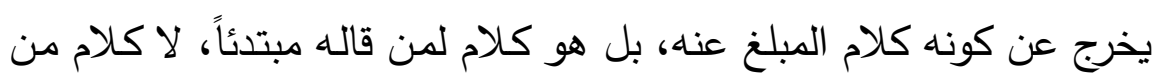
بلغه عنه مؤدياً( (r).

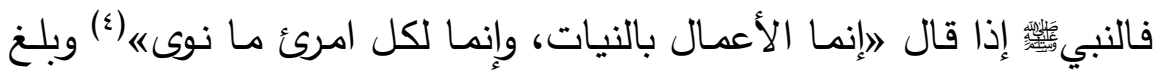
هذا الحديث عنه واحد بعد واحد حتى وصل إلينا، كان من المعلوم أنا إذا

$$
\text { (') اعتقاد أئمة الحديث (ص: OV (1) }
$$

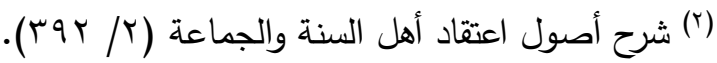

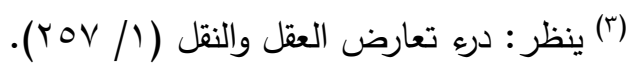

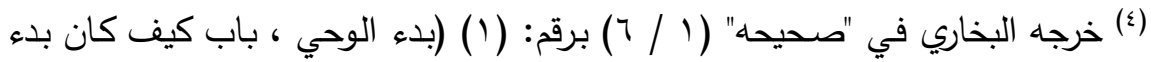

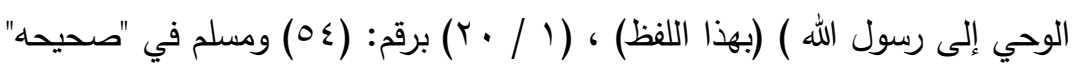

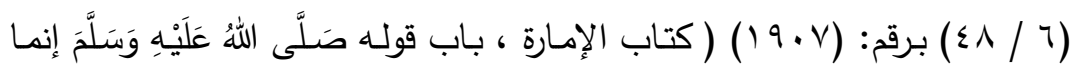
$=$ 
سمعناه من المحدث به، إنما سمعنا كلام رسول اللهاب الذي تكلم به بلفظه ومعنـاه، وإنما سمعناه من المبلـغ عنـهـ بفعله وصـوته، ونفس الصـوت الذي تكلم بـه النبيل لم نسمعه، وإنما سمعنا صوت المحدث عنـه، والكلام كـلام

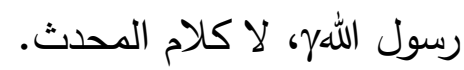
فمن قـال: إن هذا الكـلام ليس كـلام رسول اللهَيَّة، كان مفتريـاً، وكذلك من قال: إن هذا لم يتكلم بـه رسول الله صلى الله عليه وسلم، وإنمـا أحدثه في غيره، أو إنـهل لم يتكلم بلفظه وحروفه، بل كان ساكتاً أو عاجزاً عن التكلم بذلك، فعلم غيره ما في نفسـه، فنظم هذه الألفاظ ليعبر بها عما في نفس

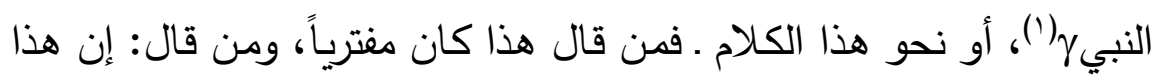

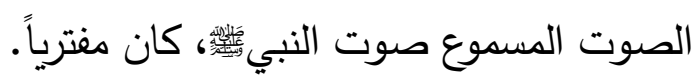
فإذا كان هذا معقولاً في كلام المخلوق، فكلام الخالق أولى بإثبات ما يستحقه

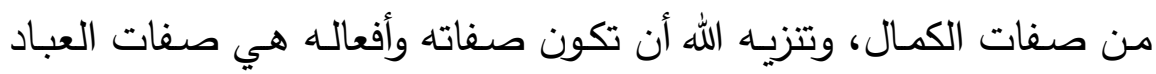
وأفعالهم، أو مثل صنات العباد وأفعالهم(؟). وقد علم أئمسة السلف أن هذا القرآن المنزل المسموع من القارئين كلام الله، كما قال تعالى : [سورة التوبة: 7]، ليس هو كلاماً لغيره، لا لفظه ولا معناه، ولكن بلغه عن الله جبريل، وبلغه محمد رسول الله هوليكي عن جبريل.

\section{الأعمال بالنية ) (بنحوه.).}

(1) وفي هذا رد على الأشاعرة والقائلين بالكلام النفسي لله عز وجل.

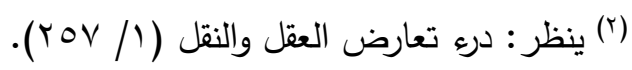




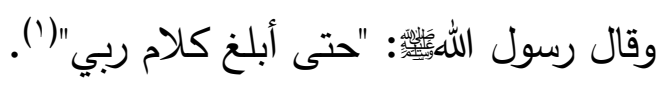

وقد علم المسلمون الفرق بين أن يسمع كلام المتكلم منه أو من المبلغ عنه،

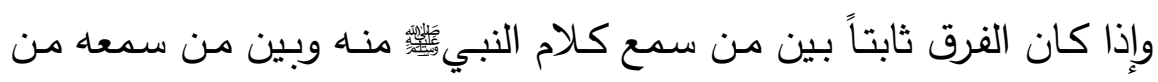
الصـاحب المبلغ عنـه، فالفرق هنا أولى، لأن أفعال المخلوق وصفاته أشبه بأفعال المخلوق وصفاته من أفعاله وصفاته بأفعال الله وصفاته(؟).

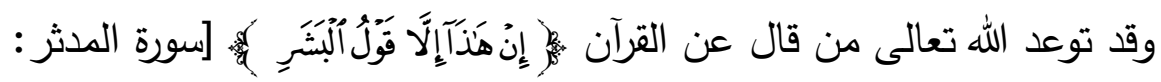
هץ] ، فمن قال: إن هذا القرآن قول البشر فقد كفر : وقال بقول الوعيد الذي

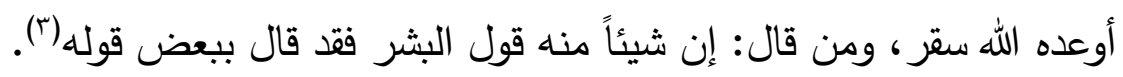

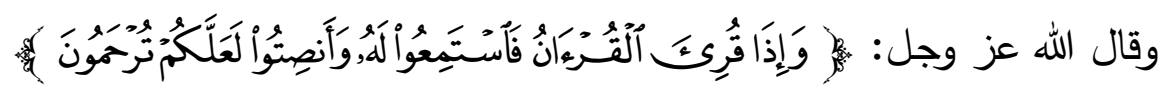

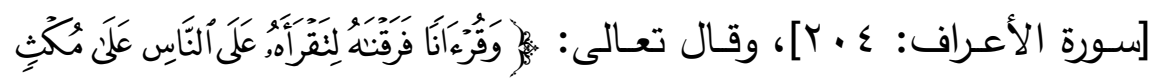

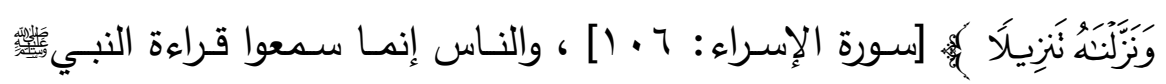
ولفظه، فلفظه بالقرآن هو القرآن.

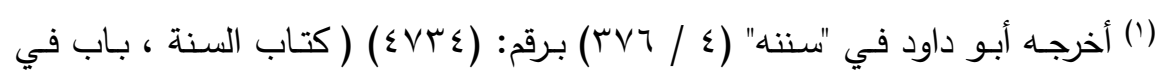

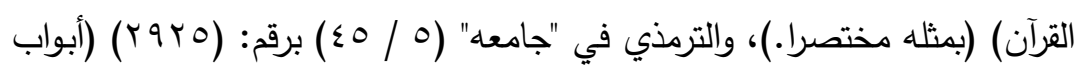

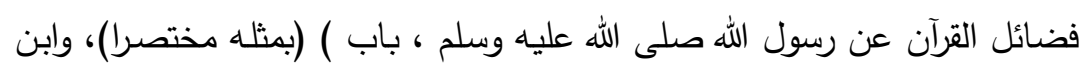

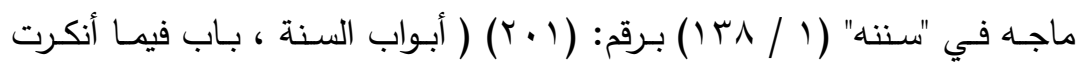

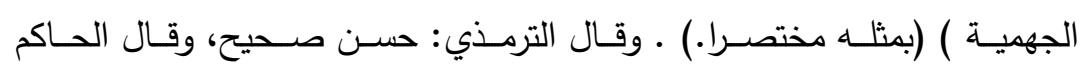

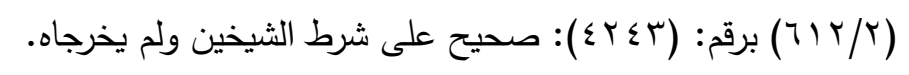

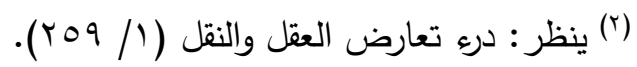

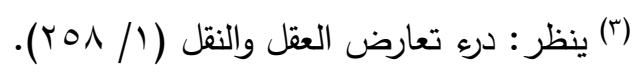




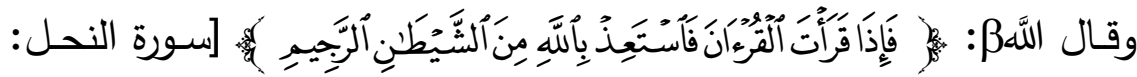

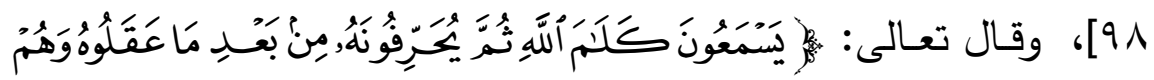

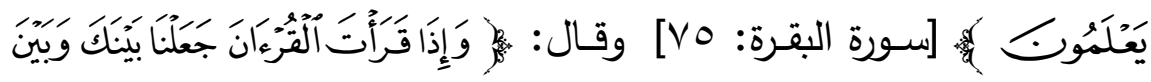

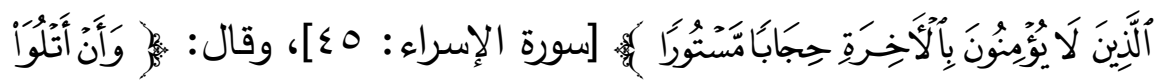

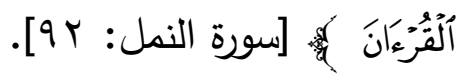

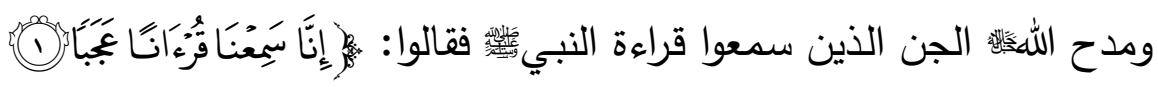

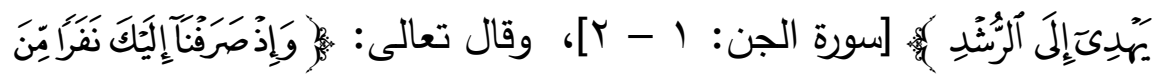

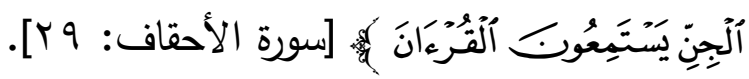

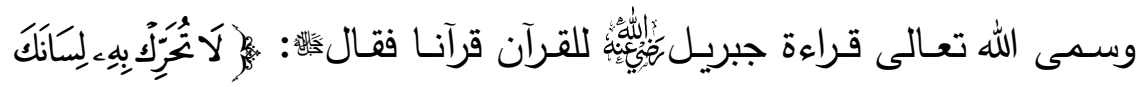

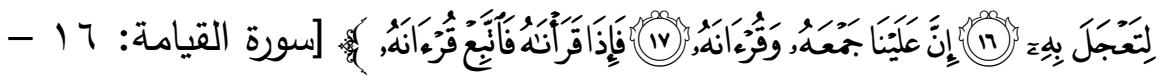

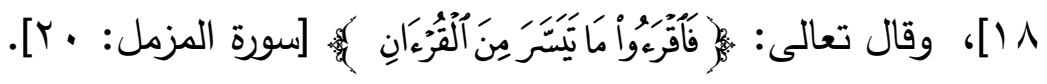
وأجمع المسلمون على أن من قرأ فاتحة الكتاب في صـلاة أنه قارئ كتاب الله تعالى، وأن من حلف ألا يتكلم فقرأ القرآن لم يحنث، فلد فل على فلى أنه ليس

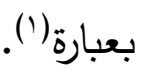

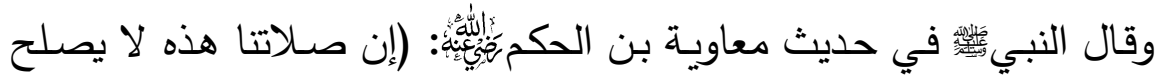

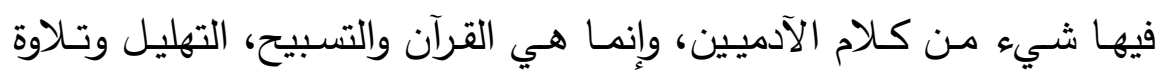

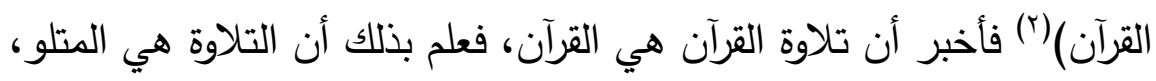

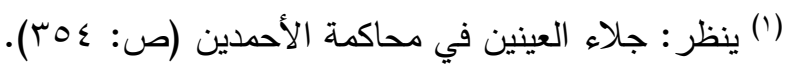

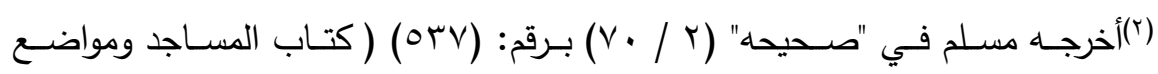
$==$ 
والله تعالى ورسولهي كانت قراءتتا كلامنا لا كلام الله تعالى لكنا مرتكبين للنهي في الصلاة. فإذا قرأ الإنسان كلام الله فالكلام كلام البارئ، ولكن الصوت صوت القارئ،

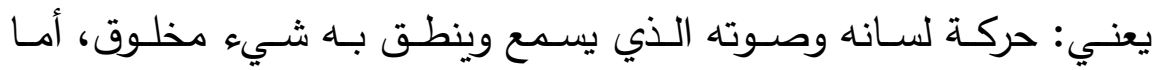
المصوت بـه المقروء المسموع منـه فهو كلام الله جل وعلا، ولهذا جاء في ولهي

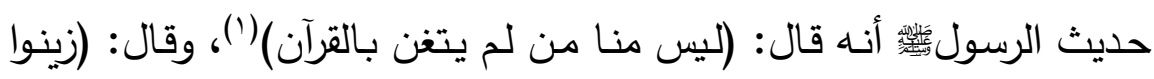
القرآن بأصواتكم)(r)، فجعل الصوت للقارئ، والمصوت بـه هو القرآن المتلو وهو كلام الله.

وقد صنف أبو أحمد بن قتيبة في هذه المسألة كتاباً، وكذلك صنف فيها أبو بكر المروذي رسالة نقلها عنه أبو بكر الخلال في كتاب السنة(؟).

الصلاة، باب تحريم الكلام فِي الصلاة ونسخ ما كان من إباحته ) (بنحوه مطولا).

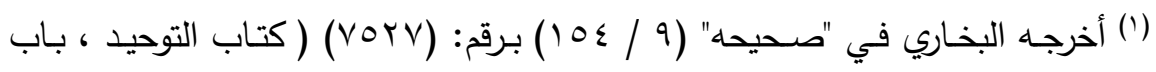
قول الله تعالى وأسروا قولكم أو اجهروا به ) (بهذا اللفظ).

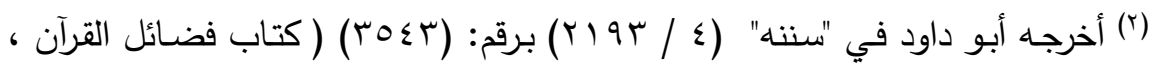

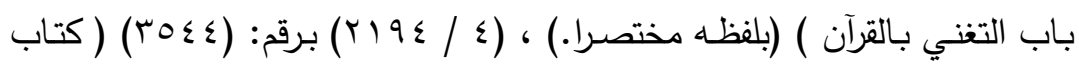

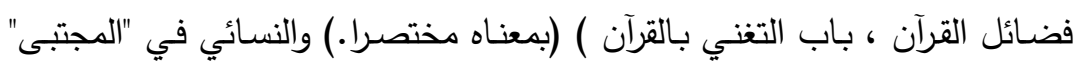

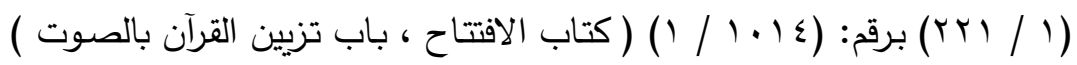

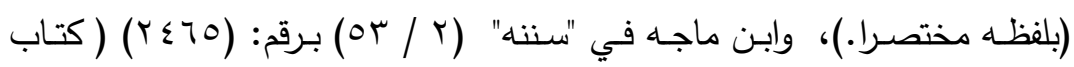
الصلاة ، باب كيف قراءة المصلي قال الله عز وجل ورتل القرآن ترتيلا ) (بلفظه مختصرا). وقال الترمذي: حسن صحيح.

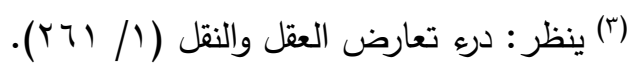


الرد على أصحاب المذهب الأول القائلين: (لفظي بالقرآن مخلوق):

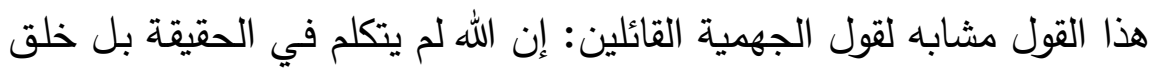

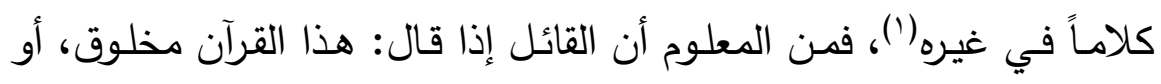

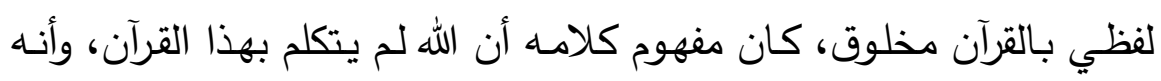

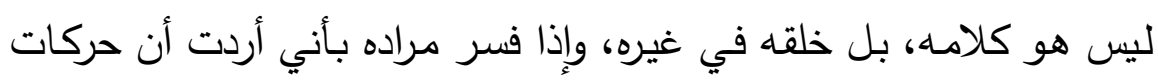

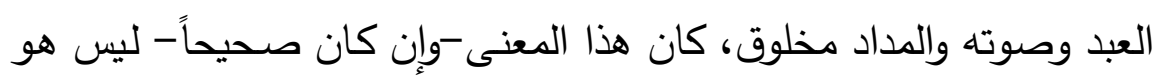
مفهوم كلامه، ولا معنى قوله، فإن المسلمين إذا قالوا: هذا القرآن كلام الله لم الم المان يريدوا بذلك أن أصوات القارئين وحركاتهم قائمة بذات الله، كما أنهم إذا قالوا:

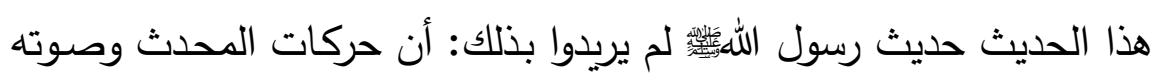

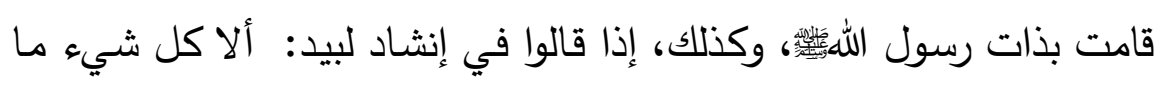

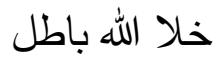

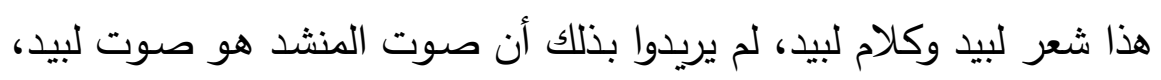

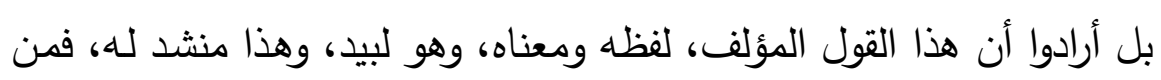

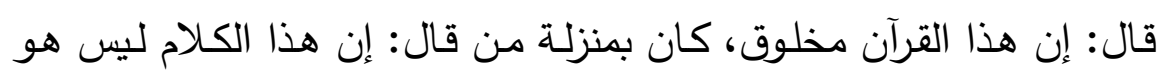

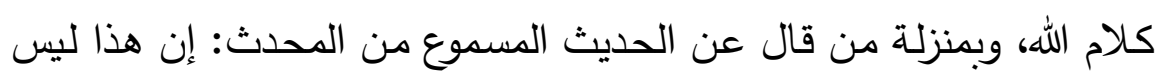

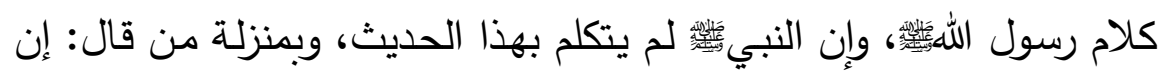

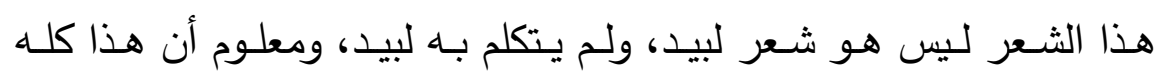

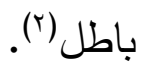

(1) من الجهمية من أطلق أن الله تكلم حقيقة، إلا أنه قال: لفظي بالقرآن مخلوق، وعلى هذا فالنزاع بينهم لفظي.

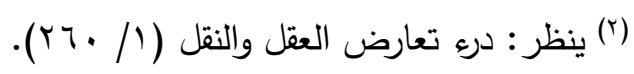


وقولهم: هذا القرآن المنزل المسموع هو تحلاوة القرآن وقراءته، وتلاوة القرآن وقراءته مخلوقة، ويدخلون في ذلك نفس الكـلام المسموع، والقرآن الملفوظ

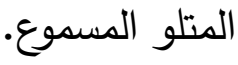
فقد تواترت النصوص عن الإمام أحمد وغيره من أئهـة السنة في إنكار هذا

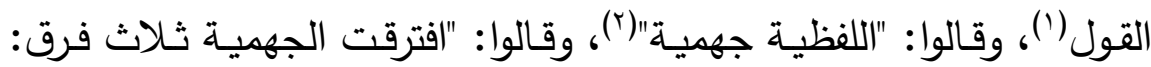
فرقـة قالت: القرآن مخلوق، وفرقـة قالت: نقف فـلا نقول مخلوق ولا غيـر مخلوق، وفرقة قالت: تلاوة القرآن واللفظ بالقرآن مخلوق"("). ولما سئل الإمام أحمد عمن قال: لفظي بالقرآن مخلوق قال: " هذا يجانب، وهو قول المبتدع، وهذا كلام الجهمية ليس القرآن بمخلوق، قالت عائشة

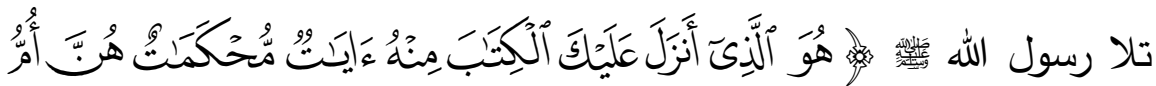

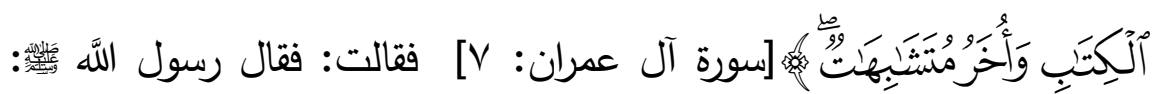

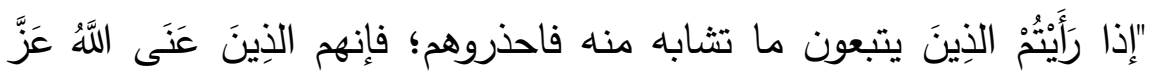
وَجَلَّ" والقرآن ليس بمخلوق"، وقال الإمام أحمد: "من قال شيء من اللهَّلَّه مخلوق علمه أو كلامه فهو زنديق كافر لا يصلى عليه، ولا يصلى خلفه ويجعل ماله كمال المرتد" وقال: "كل من يقصد إلى القرآن بلفظ أو غير ذلك

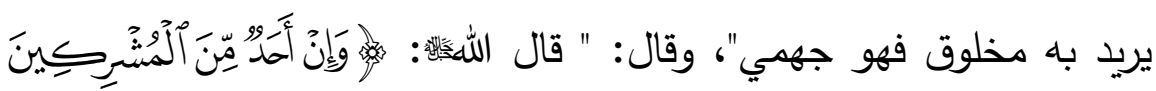

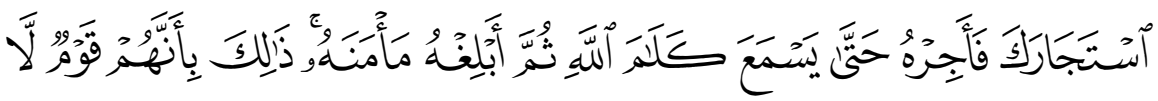

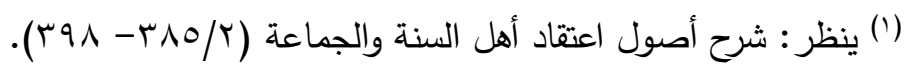

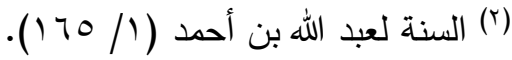

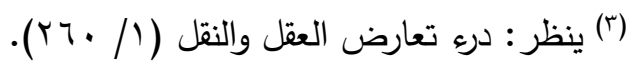




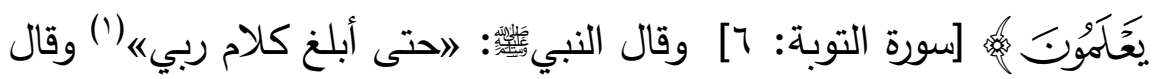

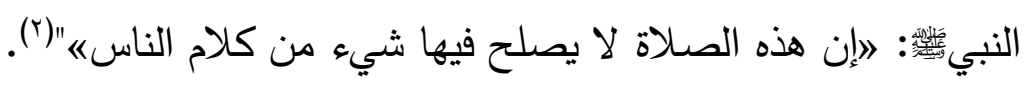
الرد على أصحاب المذهب الثاني القائلين: (لفظي قرآن غير مخلوق): لما انتثر عن بعض أهل السنة قول: (لفظي بالقرآن مخلوق)، غلطت طائفة فقالت: (لفظي بالقرآن غير مخلوق)، وقد بدع الإمـام أحمد هؤلاء، وأمـر بهجرهم، وقال: "من قال لفظي بالقرآن مخلوق فهو جهمي، ومن قال فال إنـه

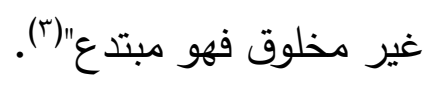

وكان مراد من قال من أهل الحديث: (لفظي بالقرآن غير مخلوق)، أن القرآن

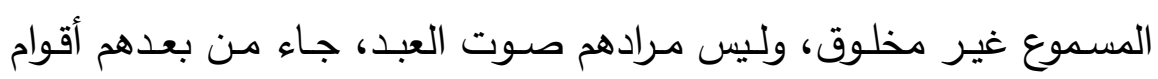

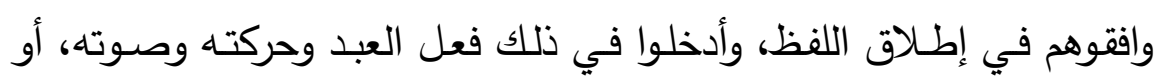

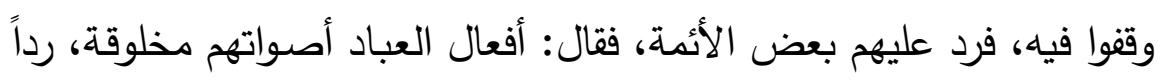

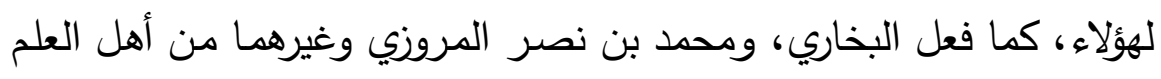

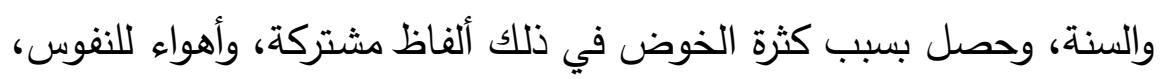

وفرقة وفتتة (ई).

وكان في قولهم (لفظي بالقرآن غير مخلوق) غلوٌ في الإثبات جمع بين حق

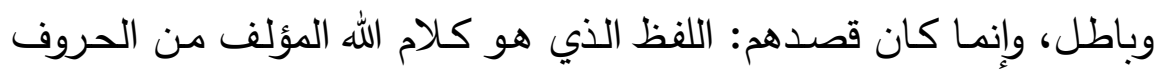

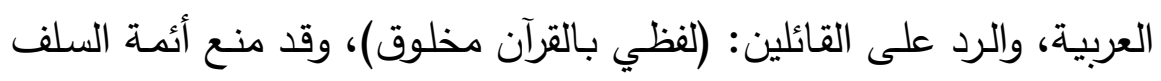

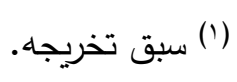

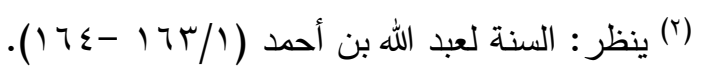

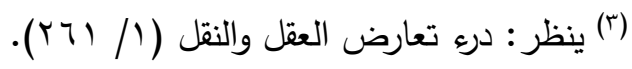

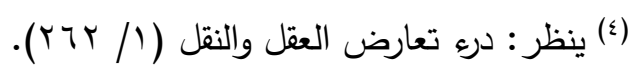


هذا اللفظ: (لفظي بـالقرآن غير مخلوق) لأنـه لفظ مبتدع، لـم يـكلم فيـه السلف، ولما يجر من الوقوع في المحذور، كما جر بعض من جاء بعد من

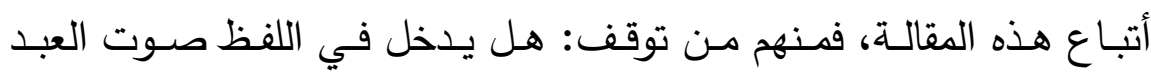

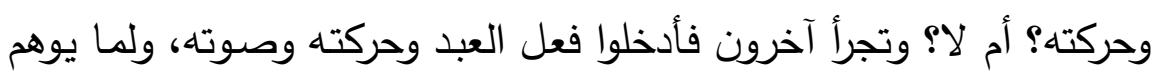
من المعاني الباطلة، كإدخال فعل القارىء وصوته في ذلك.

الاشتراك ولإجمال في "اللفظ أو التلاوة" إذ قد يراد به المفعول وهو : المقروء أو المتلو، وقد يراد به المصدر ، وهو: صوت القئ ولئ وفعله.

فمن قال من أهل السنة: اللفظ ليس هو الملفوظ، والقول ليس هو المقول، وأراد باللفظ والقول المصدر ، كان معنى كلامه: أن الحركة ليست هي الكلام المسموع، أرادوا بذلك أن أفعال العباد ليس هي كلام الله، ولا أصوات العباد هي صوت الله، وهذا صحيح. ومـن قال اللفظ هو الملفوظ، والقول هو نفسـه المقول وأراد بـاللفظ والقول مسمى المصدر ، صار حقيقة مراده أن اللفظ والقول المراد به الكلام المقول وهول هول ولهول الملفوظ المتلو، وهذا صحيح'(') فمن قال: اللفظ بالقرآن، أو القراءة، أو التلاوة، مخلوقة أو لفظي بالقرآن، أو

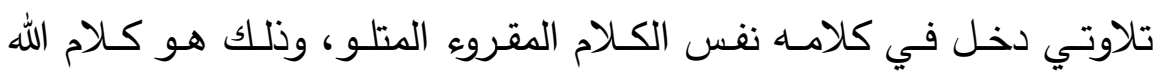


تعالى، وإن أراد بذلك مجرد فعله وصوته كان المعني صحيحاً، لكن إطلاق اللفظ يتناول هذا وغيره(').

ولهذا قال أحمد: من قال لفظي بالقرآن مخلوق يريد بـه القرآن فهو جهمي احترازاً عما إذا أراد به فعله وصوته، ومن قال: لفظي بالقرآن غير مخلوق، أو تلاوتي دخل في ذلك المصدر الذي هو علمه، وأفعال العباد مخلوقة، ولو بإن قال: أردت به أن القرآن المتلو غير مخلوق، لا نفس حركاتي قيل لـه: لفظك هوبك هذا بدعة، وفيه إجمال وإيهام، وإن كان مقصودك صحيحاً كما يقال للأول

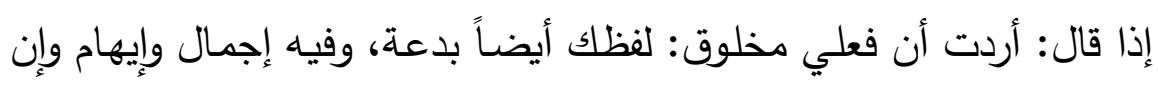
كان مقصودك صحيحاً؛ فلهذا منع أئمة السنة الكبار إطلاق هذا وهذا، وكان هذا وسطاً بين الطرفين، وكان أحمد وغيره من الأئمة يقولون: القرآن حيث تصرف كلام الله غير مخلوق(r). قال ابـن تيميـة: الأئكـة الكبـار كـانوا يمنعـون مـن إطـلاق الألفـاظ المبتدعـة المجملة المشتبهة، لما فيه من لبس الحق بالباطل مع ما توقعه من الاشتباه والاختلاف والفتنة، بخلاف الألفاظ المأثورة والألفاظ التي بينت معانيها، فإن لـان ما كان مأثوراً حصلت له الألفة، وما كان معروفا حصلت بـه المعرفة...فإذا لم يكن اللفظ منقولاً ولا معناه معقولاً ظهر الجفاء والأهواء، ولهذا تجد قوماً كثيرين يحبون قوماً ويغضون قوماً لأجل أهواء لا يعرفون معناها ولا دليلها، بل يوالون على إطلاقها أو يعادون، من غير أن تكون منقولة نقلا صحيحاً

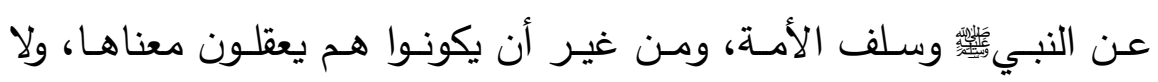

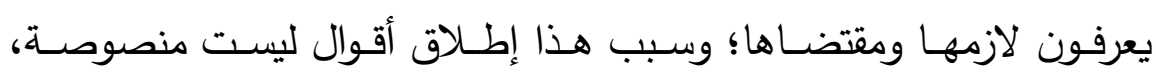

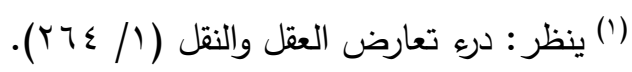

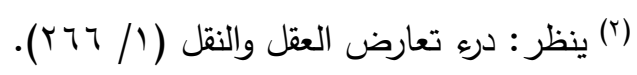


وجعلها مذاهب يدعى إليها، ويوالي ويعادى عليها، وقد ثبت في الصحيح

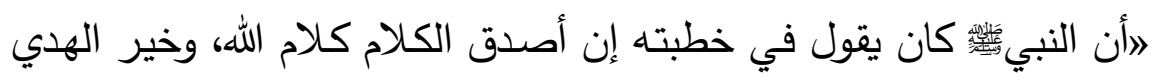

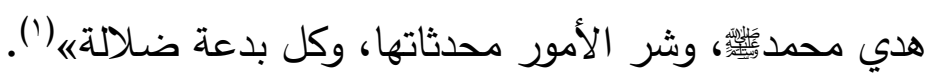

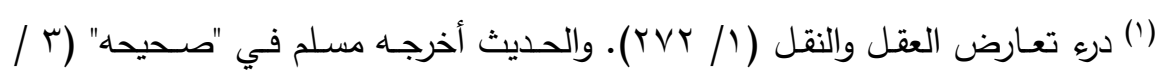
( () برقم: (^־V) ( كتاب الجمعة ، باب تخفيف الصلاة والخطبة ) (بنحوه.). 


\section{المطلب الثالث: محنة الإمام البخاري}

التعريف بالإمام البخاري:

اسمـه ونشـأته: أبو عبدالله، محمد بن إسماعيل بن إبراهيم بن المغيرة بن

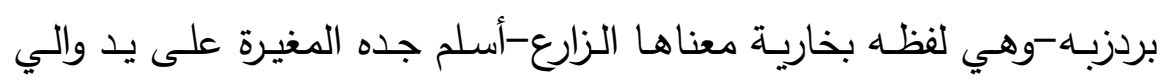
بخاري يمان الجعفي؛ لذا نسب إليهم، نسبة ولاء، كان والده إسماعيل من كبار المحدثين، ولد في بخارى في خرسان، سنة ؟ 9 اهـ، وتوفي والده وهو صـغير ؛ فنشأ في حجر أمسه، وحفظ الحديث في سن العاشرة، وقرأ الكتب المشهورة وهو ابن ست عشرة سنة.

طلبه للعلم: رحل إلى مكة مع أمه وأخيه للحج، فرجع أخوه وأمسه، ولبث في مكة يطلب الحديث، ثم زار خرسان ومصر والعراق والثام، وسمع من نحو ألف شيخ' (') ودخل بغداد ثمان مرات في كل مرة يجتمع بالإمام أحمد، وقال عنه الإمام أحمد: ما أخرجت خرسان مثله.

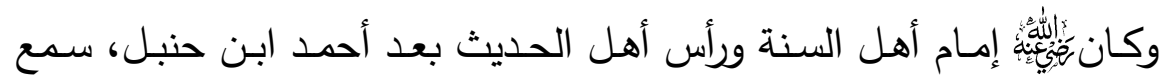
الصـيح منـه سبعون ألف رجل، وكـان يحضـر مجلسـه أكثر من عشـرين ألف.

قال ابن خزيمة: ما رأيت تحت أديم السماء أعلم بحديث رسول اللهيكائ. وأحفظ لـه من محمد بن إسماعيل، وقال عبدالله الدارمي: رأيت العلمـاء فما رأيت فيهم أجمع من البخاري.

(') منهم: محمد الأنصاري، وآدم بن أبي إياس، وسليمان بن حرب، ، وعبدالله بن حماد، وغيرهم. 
وفاته: توفي سنة كب بهـ(1).

محنة البخاري في مسألة اللفظ:

خرج البخـاري في طلب الحديث، فطـاف بلدانًا شتى، وعندما وصـل إلى نيسابور ، استقبله أهلها بولاتهم وعلمائهم، وكان في استقباله الآلاف، وأراد أن

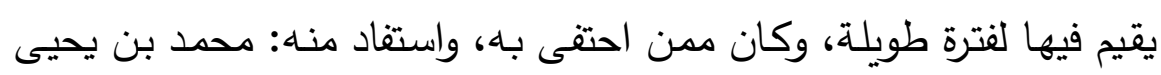
الذهلي، وقد كان ذا شأن وأتباعٍ وطاعة.

فلمـا بـدأ البخـاري في التحديث، شهد مجلسـه حضـورًا بالغًا، حتى كادت أن

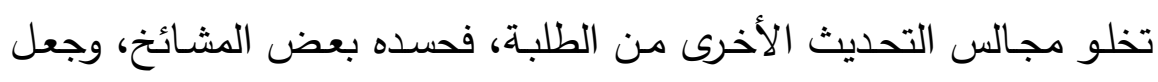
يقول لأصحاب الحديث إن البخاري يقول: إن اللفظ بالقرآن مخلوق، فامتحنوه

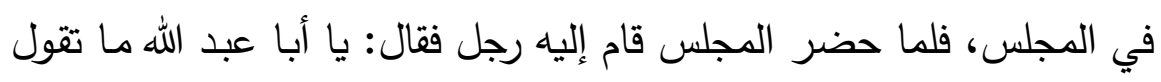
في اللفظ بالقرآن مخلوق هو أو غير مخلوق؟، فأعرض عنـه البخاري ولم يجبه ثلاثًا فألح عليه، فقال: القرآن كـلام الله غير مخلوق، وأفعال العباد مخلوقـة، والامتحــان بدعـة، فشــب الرجـل، وقـال: قـد قـال لفظـي بـالقرآن مخلوق.

فأدرك البخاري المقصد من السؤال، وأنه يراد منهه امتحانه، فقام البخاري من مجلسـ، وجلس في منزلـه، وأخذ الذهلي يخوض في حق البخـاري، فقـال البخاري: "قد قصدني هذا الرجل حسدا لما آتاني الله لا غير"(؟).

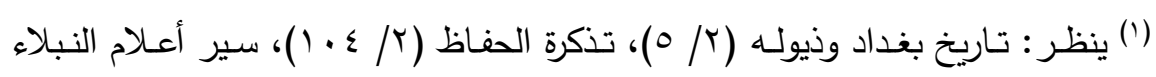

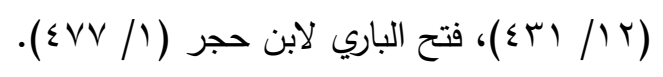

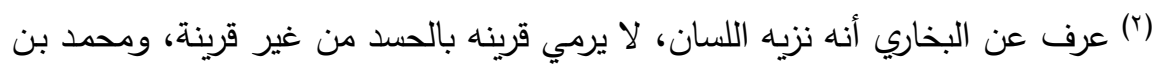

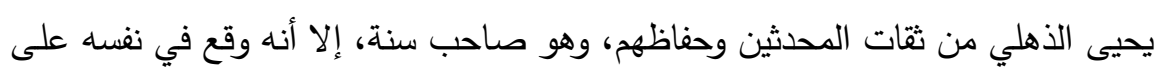
$=$ 
وروى الفربري عن البخاري أنه قال: إن أفعال العباد مخلوقة، وقال: حركاتهم وأصواتهم وأكسابهر وكتابته مخلوقة، فأما القرآن المبين المثبت في المصاحف الموعى في القلوب فهو كلام الله غير مخلوق، قال الله تعالى:

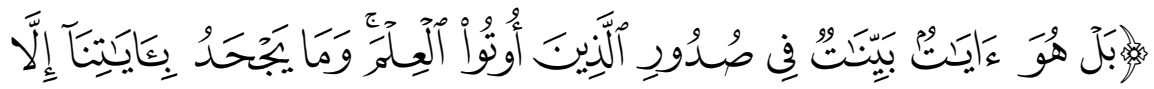

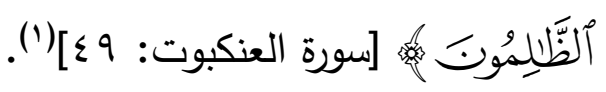

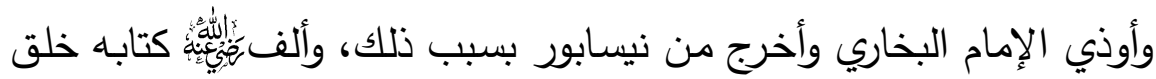

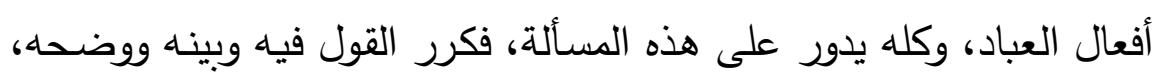
وكذلك في آخر كتابه الصحيح أيضاً ذكر ألفاظاً عدة في هذا المعنى، ومما ودها روي عنه في ذلك ما روى محمد بن نصر المروزي عن البخاري أنه قال: من زعم أني قلت: لفظي بالقرآن مخلوق، فهو كذاب، فإني لم أقله، فقال لله: يا أبا عبد الله فقد خاض الناس في هذا وأكثروا فيه. فقال: ليس إلا ما أقول

$$
\text { وأحكي لك عنه (r). }
$$

وروى أبو عمرو الخفاف عن البخاري أنه قال: من زعم من أهل نيسابور، وقومس، والري، وهمذان، وحلوان، وبغداد، والكوفة، والمدينة، ومكة، والبصرة

البخاري، وزورت إليه المقالة عليه في مسألة اللفظ، فثدد على البخاري بسببها، وجرت عادة أهل العلم في كلام الأقران في بعضهم أنه يطوى ولا يروى.

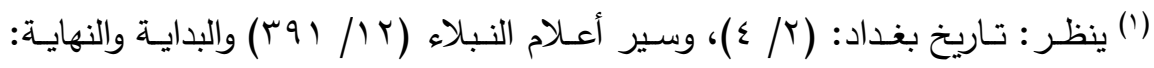

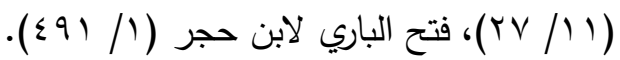

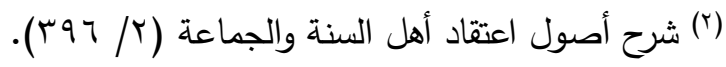


أني قلت: لفظي بالقرآن مخلوق، فهو كذاب، فإني لم أقل هذه المقالة، إلا أني قلت: أفعال العباد مخلوقة (1).

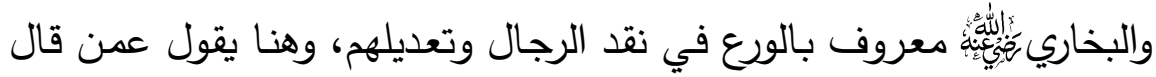

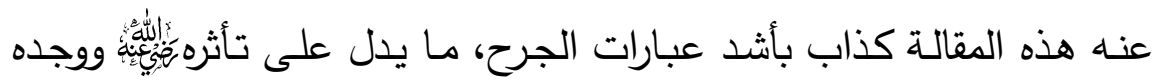
على من رماه بذلك. 


\section{الخاتقة}

أحمد الله سبحانه وتعالى وأثني عليه أن يسر لي إتمام البحث، ومن أبرز النتائج:

- - ظهـرت فتتـة القول بخلق القرآن في عهد المـأمون، وامـتُحن فيهـا العلماء ومنهم: الإمام أحمد، الذي نصر الله به الدين.

- - المقصـود بـاللفظ في البحث: هـو قـول القائـل: "إن اللفظ بـالقرآن

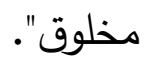
- أول من قال: "لفظي بالقرآن مخلوق" هو الكرابيسي. - - تعددت مذاهب العلمـاء في هذه المسألة إلى ثلاثة أقوال: الإثبات

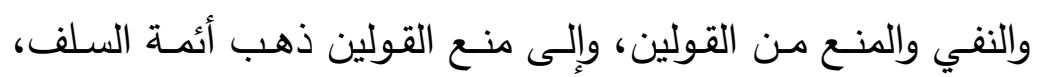

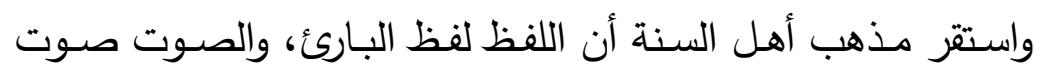

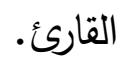
- امتُحن الإمام البخاري في هذه المسألة وقد نفى مذلك عن نفسـه، ووافق الإمام أحمد فيما ذهب إليه، ما يوضح اتفاق منهج أهل السنة رغم اختلاف الزمان والمكان. 


\section{التوصيات}

- الاهتمام بسير علماء الأمة وبيان بذلهم وتحملهم وابتلائهم، وتسليط الضوء على ذلك.

- إقامــة مناشـط علميـة مـن ملتقيـات ومـؤتمرات تتـاقش المسـتجدات والنوازل، وبيان المنهج الحق فيها.

- - التركيز على نشر وبيان منهج السلف في تلقي العقيدة والاستدلال لها، والاستفصال في المسائل المجملة الموهومة. هذا والله أعلم وصلى الله على نبينا محمد وعلى آله وصحبه وسلم. 


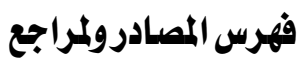

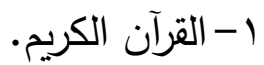

r-اعتقاد أئعة الحديث، المؤلف: أبو بكر أحمد بن إبراهيم بن إسماعيل بن

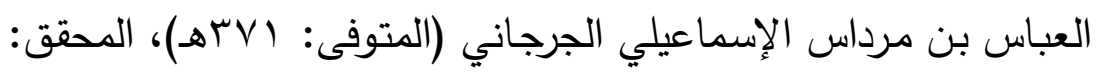

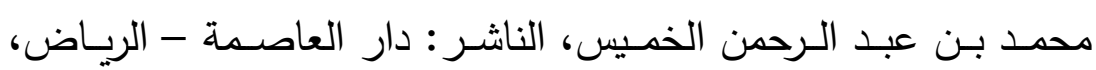

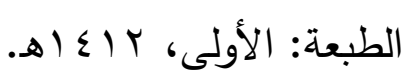

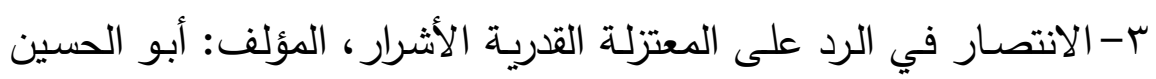

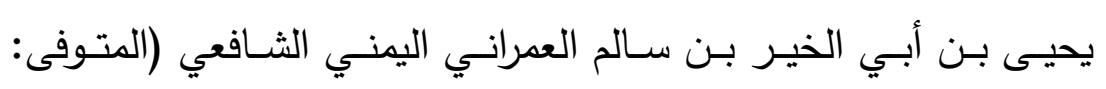

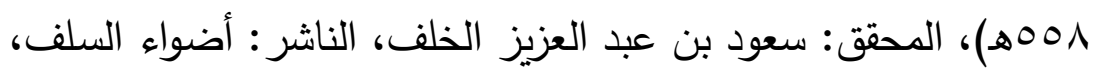

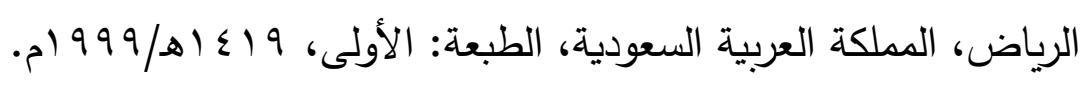

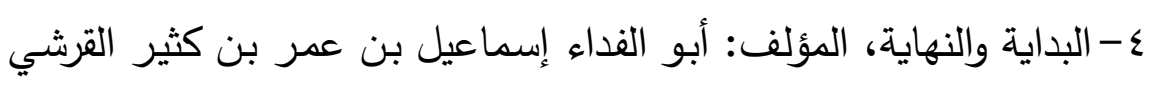

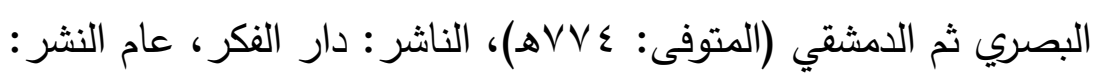

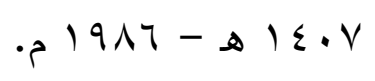

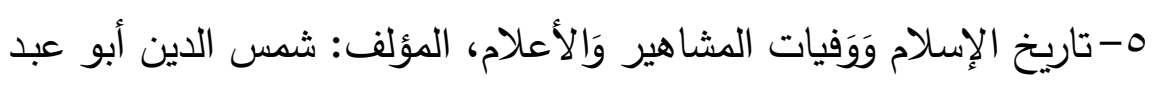

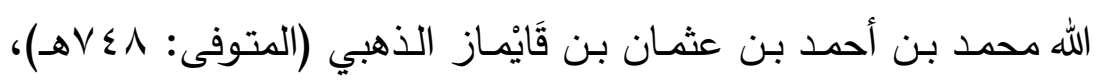

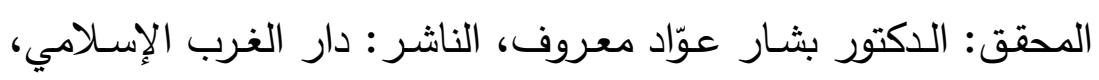

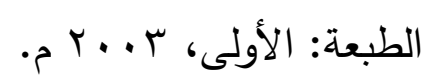

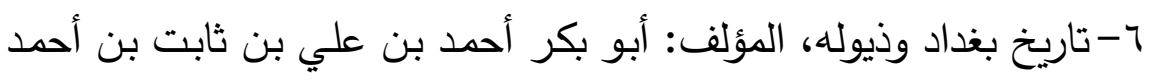

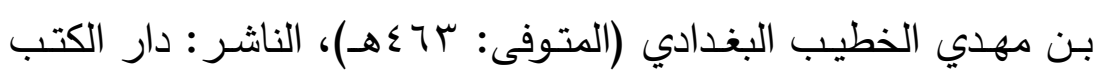
العلمية - بيروت، دراسة وتحقيق: مصطفى عبد القادر عطا، الطبعة:

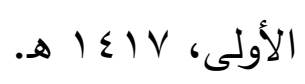

V-تذكرة الحفاظ، المؤلف: شمس الدين أبو عبد الله محمد بن أحمد بن 
عثمان بن قَايْماز الذهبي (المتوفى: \^هـ)، الناشر: دار الكتب العلمية

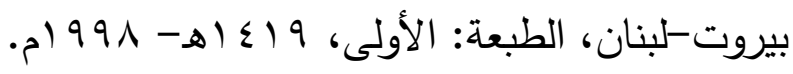
A- التعريفات، المؤلف: علي بن محمد بن علي الزين الثريف الجرجاني (المتـوفى: 7 ( 1 هـ)، المحقق : ضـبطه وصـححه جماعـة مـن العلمـاء بإشـراف الناشـر ، الناشـر: دار الكتب العلميـة بيـروت ــلبنـان، الطبعـة:

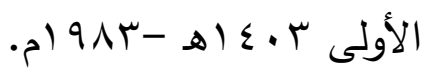

9- التوقيف على مهمات التعاريف، المؤلف: زين الدين محمد المدعو بعبد الرؤوف بن تاج العارفين بن علي بن زين العابدين الحدادي ثم المناوي

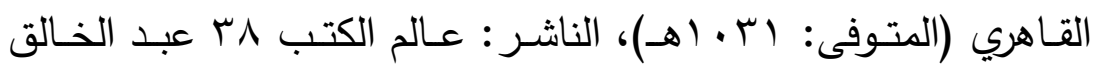

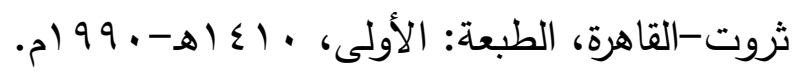

• - - جزء فيه ذكر اعتقاد السلف في الحروف والأصوات، المؤلف: أبو زكريا محيي الدين يحيى بن شرف النووي (المتوفى: جلجهـ)، المحقق:

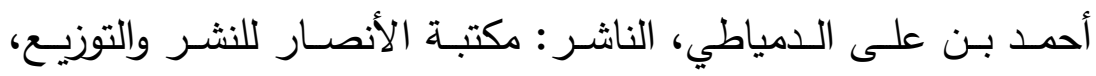
الطبعة: الأولى. - الطي.

11- جلاء العينين في محاكمة الأحمدين، المؤلف: نعمان بن محمود بن عبد الله، أبو البركات خير الدين، الآلّوسي (المتوفى: V Vاس اهـ)، قدم له: علي السيد صبح المدني - رحمـه الله -، الناشر : مطبعة المدني، عام

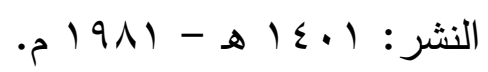

r ا- - درو تعارض العقل والنقل، المؤلف: تقي الدين أبو العباس أحمد بن عبد الحليم بن عبد السلام بن عبد الله بن أبي القاسم بن محمد ابن تيمية

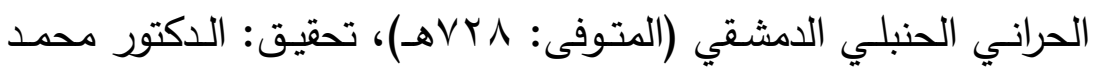
رشاد سـالم، الناشر : جامعة الإمـام محمد بن سعود الإسـلامية، المملكة العربية السعودية، الطبعة: الثانية، 11 إل هـ - 1991 م. 


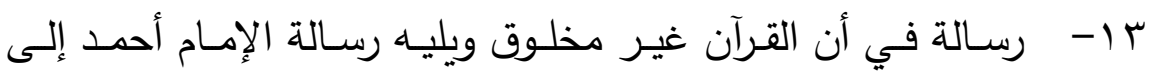
الخليفـة المتوكل في مسـألة القـرآن، المؤلفـف: أبـو إسـاق إبـراهيم بـن إسـحاق بـن إبراهيم بـن بشير بـن عبد الله البغدادي الحَرْبي (المتوفى:

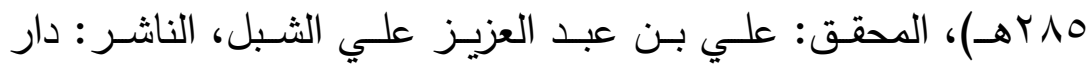

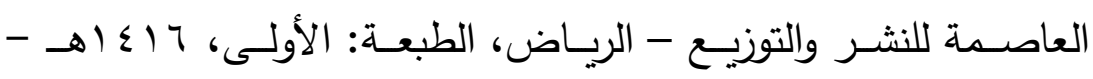
. $) 990$

ع ا- - السنة، المؤلف: أبو عبد الرحمن عبد الله بـن أحمد بن محمد بـن حنبل الثيبانيّ البغدادي (المتوفى: 9 وهـ)، المحقق: د. محمد بن سعيد

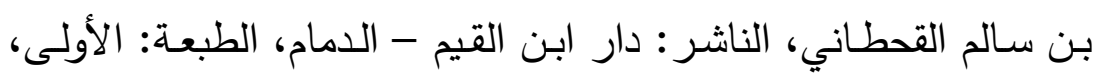

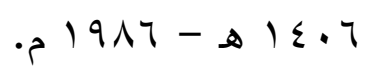

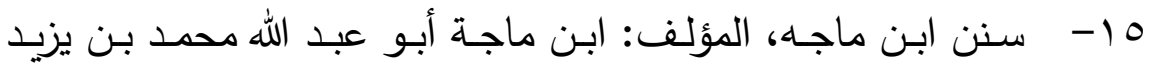
القزويني، وماجة اسم أبيه يزيد (المتوفى: س ب به)، تحقيق: محمد فؤاد عبد الباقي، الناشر : دار إحياء الكتب العربية - فيصل عيسى البابي الحلبي.

7 ا - سنن أبي داود، المؤلف: أبو داود سليمان بن الأشعث بن إسحاق بن

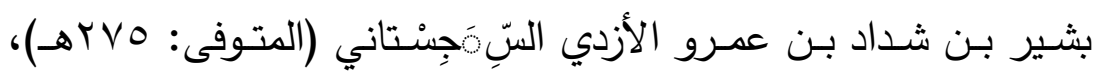
المحقق: محمد محيـي الدين عبد الحميد، الناشـر : المكتبـة العصـرية،

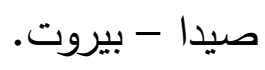

IV - سنن الترمذي، المؤلف: محمد بن عيسى بن سَوْرة بن موسى بن

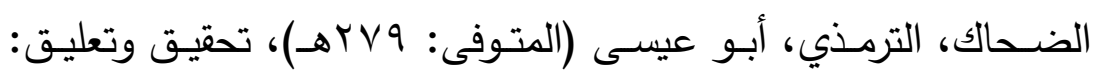

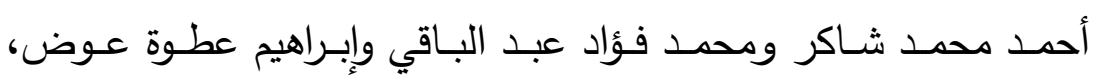
الناشر : شركة مكتبة ومطبعة مصطفى البابي الحلبي - مصر •

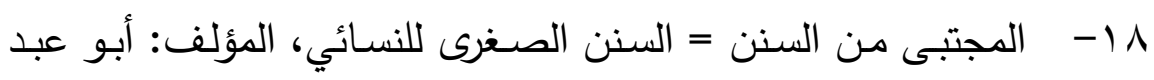


الـرحمن أحمـــــن شـعيب بـن علـي الخراســـي، النسـائي (المتـوفى:

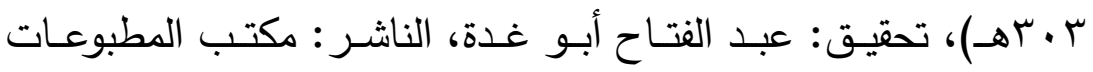

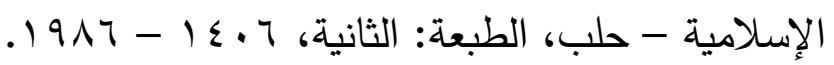

9 1 - سير أعـلام النبلاء، المؤلف : شمس الدين أبو عبد الله محمد بن

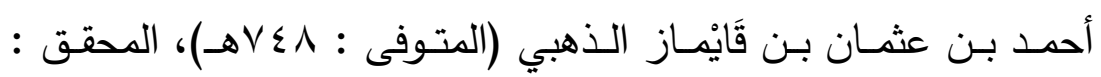
مجموعة من المحققين بإشراف الشيخ شعيب الأرناؤوط

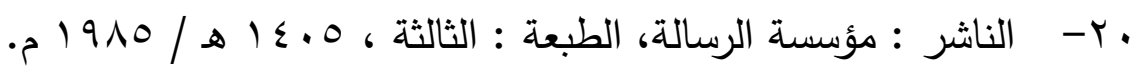

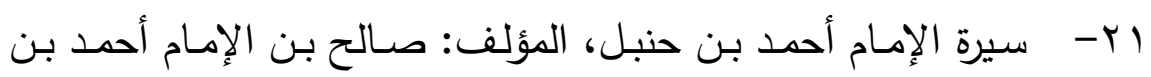

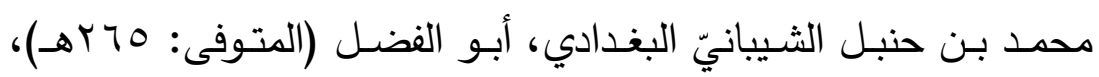

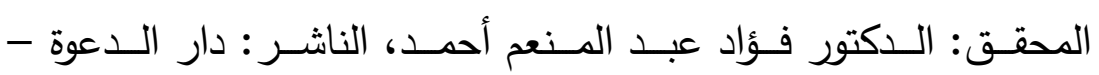
الإسكندرية، الطبعة: الثانية، ع • ع اهـ.

Y Y - شرح أصول اعتقاد أهل السنة والجماعة، المؤلف: أبو القاسم هبة الله بن الحسن بـن منصـور الطبري الرازي اللالكائي (المتوفى: 1 (اءهـ)، تحقيـق: أحمـد بـن سـعد بـن حمـدان الغامـدي، الناشـر : دار طيبـة -

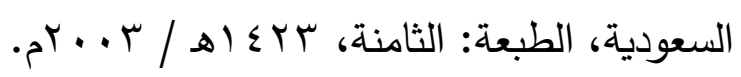
rr- شرح السنة، المؤلف: أبو محمد الحسن بن علي بن خلف البربهاري

$$
\text { (المتوفى: و وبهـ). }
$$

ع - - شرح العقيدة الطحاويـة، المؤلف: صدر الدين محمد بن علاء الدين عليّ بـن محمـد ابـن أبسي العز الحنفي، الأذرعي الصـالحي الدمشـي (المتوفى: Y Y Yهـ)، تحقيق: جماعـة من العلماء، تخريج: ناصـر الدين

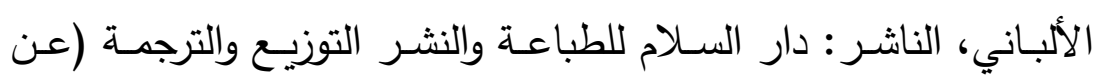

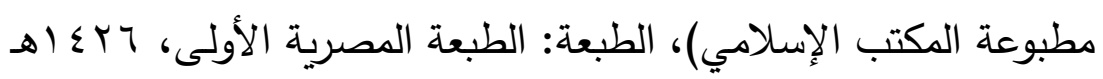
$.5 r \cdot 0-$ 
0ب- صحيح الجامع الصغير وزياداته، المؤلف: أبو عبد الرحمن محمد ناصـر الدين، بـن الحساج نـوح بـن نجاتي بـن آدم، الأشقودري الألباني

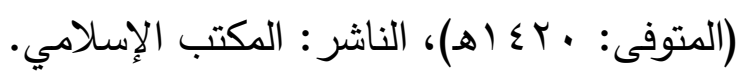

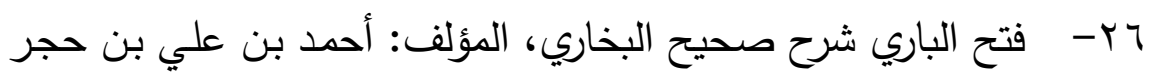

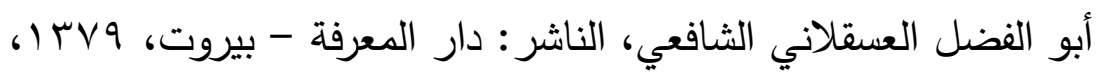

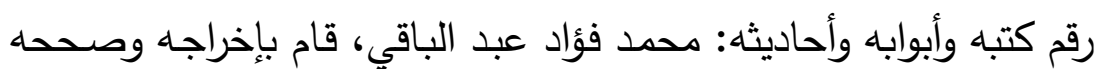
وأشرف على طبعه: محب الدين الخطيب.

- - - لسان العرب، المؤلف: محمد بن مكرم بن على، أبو الفضل، جمال الـدين ابن منظسور الأنصساري الرويفعى الإفريقى (المتوفى: (Iالهـ)،

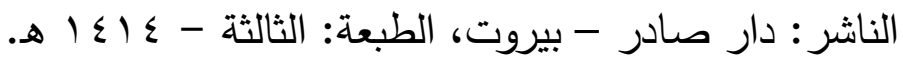

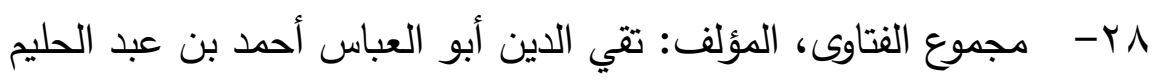
ابن تيمية الحراني (المتوفى: هY هـ)، المحقق: عبد الرحمن بن محمد ابن قاسم، الناشر : مجمع الملك فهد لطباعة المصحف الشريف، المدينة النبوية، المملكة العربية السعودية، عام النشر: 7 إـ اله/990 إم. qץ- مختار الصحاح، المؤلف: زين الدين أبو عبد الله محمد بن أبي بكر المر ابن عبد القادر الحنفي الرازي (المتوفى: ج77هـ)، المحقق: يوسف الثيخ محمد، الناشر : المكتبة العصرية - الدار النموذجية، بيروت - صيدا، الطبعة: الخامسة، ، ب \& اهـ / 999 (م.

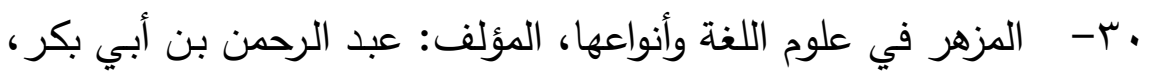
جلال الدين السيوطي (المتوفى: 119هـ)، المحقق: فؤاد علي منصور ،

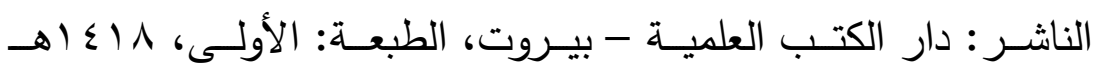
- $) 991$ اب- المصباح المنير في غريب الشرح الكبير ، المؤلف: أحمد بن محمد 
ابن علي الفيومي ثم الحموي، أبو العباس (المتوفى: نحو • •Vهـ)، الناشر : المكتبة العلمية - بيروت.

rr- معجم مقاييس اللغة، المؤلف: أحمد بن فارس بن زكريـاء القزويني

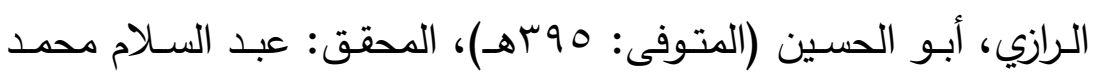

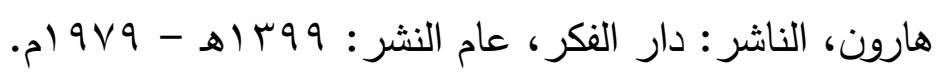
rr- مناقب الإمام أحمد، المؤلف: جمال الدين أبو الفرج عبد الرحمن بن علي بن محمد الجوزي (المتوفى: V9 Vهـ)، المحقق: د. عبد الله بن عبد الإمان

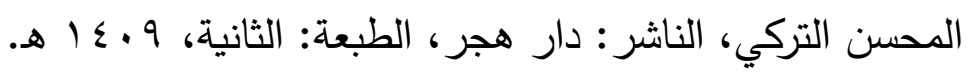
ع - - موسـوعة كثـاف اصـلاحات الفنون والعلوم، المؤلف: محمـ بـن علي ابن القاضي محمد حامد بن محمّد صابر الفاروقي الحنفي التهانوي

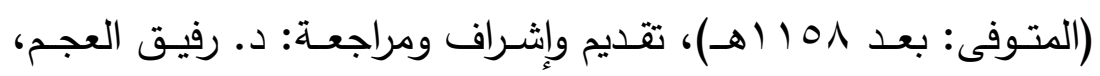

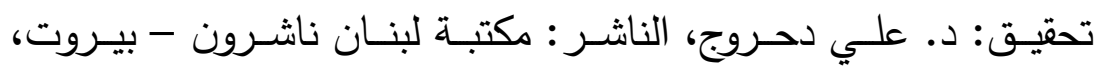

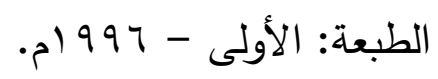

هـ- وفيـات الأعيان وأنباء أبنـاء الزمـان، المؤلف: أبـو العبـاس شـس الدين أحمد بن محمد بن إبراهيم بن أبي بكر ابن خلكان البرمكي الإربلي

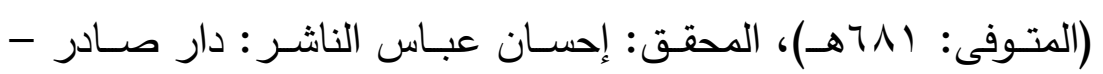


فهرس الموضوعات

المقدمة.

التمهيد: التعريف بالإمام أحمد...

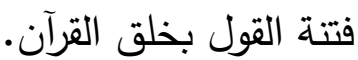
المطلب الأول: التعريف باللفظية... المسألة الأولى: تعريف اللفظية. المسألة الثانية: نشأة القول باللفظية.... المطلب الثاني: مذاهب العلماء في اللفظية... المطلب الثالث: محنة الإمام البخاري.... المسألة الأولى: التعريف بالإمام البخاري... المسألة الثانية: محنة البخاري في مسألة اللفظ. الخاتمة. فهرس المصادر والمراجع... -

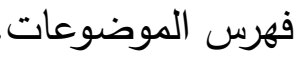

